\title{
From the prion-like propagation hypothesis to therapeutic strategies of anti-tau immunotherapy
}

\author{
Morvane Colin $^{1,6} \cdot$ Simon Dujardin ${ }^{1,2} \cdot$ Susanna Schraen-Maschke ${ }^{1} \cdot$ Guy Meno-Tetang ${ }^{3} \cdot$ Charles Duyckaerts $^{4}$. \\ Jean-Philippe Courade ${ }^{5}$. Luc Buée ${ }^{1,6}$
}

Received: 28 May 2019 / Revised: 18 October 2019 / Accepted: 19 October 2019 / Published online: 4 November 2019

(c) The Author(s) 2019

\begin{abstract}
The term "propagon" is used to define proteins that may transmit misfolding in vitro, in tissues or in organisms. Among propagons, misfolded tau is thought to be involved in the pathogenic mechanisms of various "tauopathies" that include Alzheimer's disease, progressive supranuclear palsy, and argyrophilic grain disease. Here, we review the available data in the literature and point out how the prion-like tau propagation has been extended from Alzheimer's disease to tauopathies. First, in Alzheimer's disease, the progression of tau aggregation follows stereotypical anatomical stages which may be considered as spreading. The mechanisms of the propagation are now subject to intensive and controversial research. It has been shown that tau may be secreted in the interstitial fluid in an active manner as reflected by high and constant concentration of extracellular tau during Alzheimer's pathology. Animal and cell models have been devised to mimic tau seeding and propagation, and despite their limitations, they have further supported to the prion-like propagation hypothesis. Finally, such new ways of thinking have led to different therapeutic strategies in anti-tau immunotherapy among tauopathies and have stimulated new clinical trials. However, it appears that the prion-like propagation hypothesis mainly relies on data obtained in Alzheimer's disease. From this review, it appears that further studies are needed (1) to characterize extracellular tau species, (2) to find the right pathological tau species to target, (3) to follow in vivo tau pathology by brain imaging and biomarkers and (4) to interpret current clinical trial results aimed at reducing the progression of these pathologies. Such inputs will be essential to have a comprehensive view of these promising therapeutic strategies in tauopathies.
\end{abstract}

Keywords Immunotherapy $\cdot$ Alzheimer's disease $\cdot$ Seeding $\cdot$ Progressive supranuclear palsy $\cdot$ Secretion $\cdot$ CSF $\cdot$ Plasma $\cdot$ $\mathrm{Tau}$

Morvane Colin, Simon Dujardin and Susanna Schraen-Maschke co-first authors.

\footnotetext{
Morvane Colin

morvane.colin@inserm.fr

$\triangle$ Luc Buée

luc.buee@inserm.fr

1 Univ. Lille, Inserm, CHU-Lille, Lille Neuroscience and Cognition, Place de Verdun, 59045 Lille, France

2 Mass General Institute for Neurodegenerative Disease, Massachusetts General Hospital, Harvard Medical School, Charlestown, MA, USA
}

\section{Introduction}

Alzheimer's disease (AD) is a genuine challenge for the pharmaceutical industry. The current drugs on the market show only low efficacy, and the clinical trials of the last 20 years have all been negative in phase 3 . With the hegemony of the amyloid cascade hypothesis and the focus on

3 UCB Celltech, 208 Bath Rd, Slough SL1 3WE, UK

4 Department of Neuropathology, Sorbonne Université, Assistance Publique Hôpitaux de Paris, Inserm, CNRS, Institut du Cerveau Et de La Moelle, Hôpital Pitié-Salpêtrière, 75013 Paris, France

5 UCB Biopharma, Chemin du Foriest, 1420 Braine l'Alleud, Belgium

6 Inserm UMR-S 1172, 'Alzheimer and Tauopathies', Bâtiment Biserte, rue Polonovski, 59045 Lille Cedex, France 
amyloid precursor protein (APP) and its metabolites (A $\beta$ and amyloid precursor protein intracellular domain: AICD), therapeutic strategies targeting tau protein, a major component of neurofibrillary tangles and neuropil threads, have emerged only in recent years. However, tau aggregates not only in $\mathrm{AD}$, but also in many other highly heterogeneous pathologies called tauopathies. Understanding tau and tauopathies is essential before designing a therapeutic approach. Tau may be an excellent therapeutic target, but should the strategy be similar among tauopathies? The hypothesis of the amyloid cascade has oriented most of the research towards APP and $\mathrm{A} \beta$; in the tau field, the hypothesis of a prion-like propagation has similarly captured the research effort and oriented the new therapeutic approaches such as immunotherapy into new directions.

In this review, we combined the data obtained in humans and those generated from experimental models in the context of the prion-like propagation hypothesis for tauopathies. We evaluated the current knowledge of tau biology in intra- and extracellular compartments (brain and peripheral fluids), described recent breakthroughs, and highlighted some unanswered questions. Finally, with this knowledge, we wondered whether we could predict the mode of action and the target engagement of immunotherapy approaches among tauopathies.

\section{Tau isoforms and inclusions}

The advance of immunohistochemistry has revealed that approximately 20 neurodegenerative diseases, named tauopathies, are characterized by the accumulation of hyperphosphorylated tau (pTau) [165]. Tau is encoded by a single gene (MAPT) located on chromosome 17. The MAPT gene is mostly expressed in neurons [27], and due to alternative splicing of exons 2, 3 and 10, six main isoforms are found in the adult brain: $2-3-10-(0 N 3 R), 2+3-10-(1 N 3 R), 2+3+10-(2 N 3 R)$, $2-3-10+(0 N 4 R), 2+3-10+(1 N 4 R), \quad$ and $2+3+10+(2 \mathrm{~N} 4 \mathrm{R})[5,81]$ (Fig. 1a).

Tau protein has four domains with unique biochemical characteristics and specific functions: (i) an acidic aminoterminal domain, (ii) a proline-rich region followed by (iii) microtubule-binding regions (MTBR) and (iv) a carboxyterminal tail. The microtubule-binding regions contain three or four repeat domains (depending on the inclusion of exon 10) [38, 82, 90, 114] (Fig. 1b). Several post-translational modifications (PTMs) have been described on tau proteins [87]; phosphorylation dynamically regulates the physiological functions of tau [133, 160]. In tauopathies, tau is excessively and abnormally phosphorylated [10]. Other PTMs (acetylation, glycation, glycosylation, methylation, SUMOylation, truncation, ubiquitinylation, etc.) have also been described; some of them, such as acetylation, glycosylation and truncation, may also be related to the pathology and are considered as therapeutic targets [100].

pTau may accumulate in the cell bodies of neurons without forming fibrillary aggregates-a change called a "pre-tangle". Moreover, pTau may aggregate in the cell bodies of neurons (neurofibrillary tangles $=$ NFTs) or in the cell processes (neuropil threads $=\mathrm{NT}$ ), and NT may be axonal (as in the corona of the senile plaque) or dendritic. Under electron microscopy, tau aggregates are principally made of paired helical filaments (PHF) in AD (3R and 4R), which is also the case in 'primary age related tauopathy' (PART) in chronic traumatic encephalopathy (CTE) and in some less-common disorders (see Fig. 2). In progressive supranuclear palsy (PSP) and cortico-basal degeneration (CBD), tau aggregates are found both in neurons and glia and are made of $4 \mathrm{R}$ straight tau filaments. Other specific neuronal tau inclusions are Pick bodies (seen in Pick disease), in which 3R tau aggregates in the neuronal cell body adopt a spherical shape, and argyrophilic grains made of 4R tau (seen in argyrophilic grain disease (AGD)) are located in presynaptic terminals. The glial inclusions may involve astrocytes: in astrocytic tufts, suggestive of PSP, all processes of the astrocyte are filled with pTau; in astrocytic plaques, seen in CBD, pTau immunoreactivity is found at the end of the astrocytic processes [108, 110]; and they may involve oligodendrocytes where they form coiled bodies (abundant in PSP, CBD and AGD). The ratio between 3 and $4 R$ tau explains why specific sets of migration bands have been recognized by Western blotting (Fig. 2). Recent structural studies by cryo-electron microscopy have confirmed the presence of different tau structures among AD, Pick's disease and CTE [67, 68, 71].

Genetic frontotemporal lobar degeneration (FTLDMAPT formerly called FTDP-17, [74]) is of particular interest. It is caused by autosomal dominant MAPT mutations mainly located in the sequence regulating exon 10 alternative splicing or encoding microtubule-binding regions. Most coding region mutations often act on both nucleation and fibrillogenesis $[12,36]$. They are widely used for studying the pathological mechanisms of tauopathies, especially in animal models [61].

Altogether, tauopathies are the consequence of several molecular dysfunctions likely due to PTM and protein-folding deregulations. These deregulations are associated with the development of conformational changes, oligomerization and finally, intracytoplasmic aggregation of tau. All these processes have a significant impact on cell physiology and particularly on tau functions [164] (Fig. 3). Neuropathology, however, shows the large variety of cerebral areas and cell populations (glial or neuronal) affected; it also indicates that the type of tau aggregation is diverse, as shown 


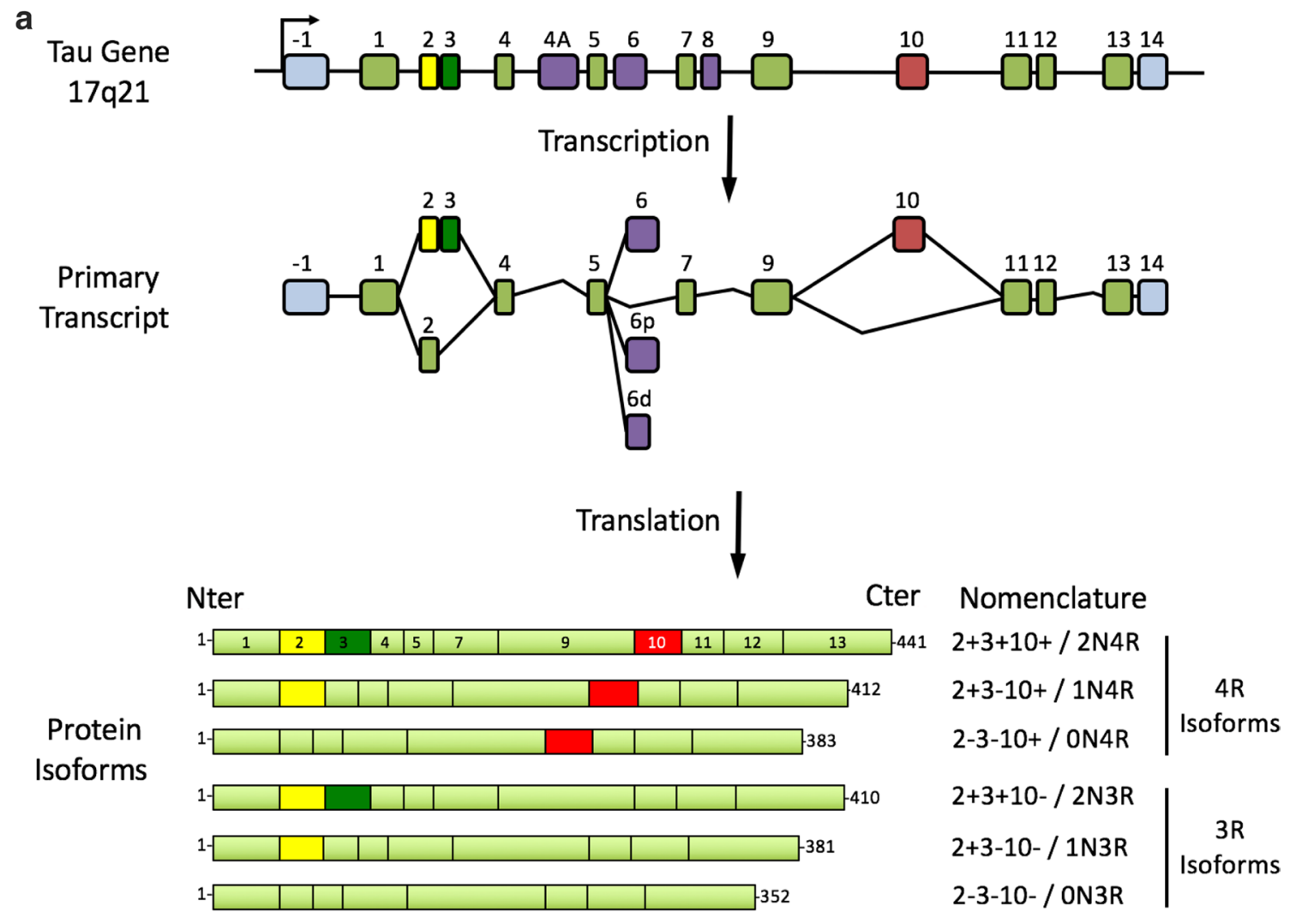

b

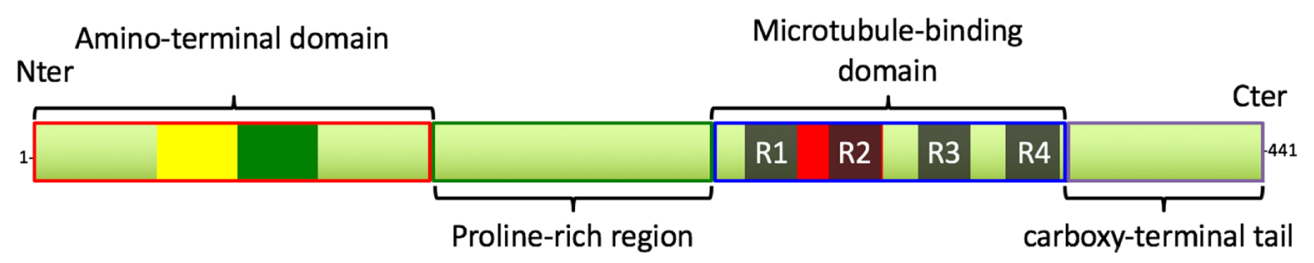

Fig. 1 a Schematic presentation of the MAPT gene, its primary transcript and the six protein isoforms expressed in the human brain. The MAPT gene is composed of 16 exons. In the brain, exons 4A and 8 are excluded from the primary transcript. Exons 1, 4, 5, 7, 9, 11, 12 and 13 are constitutive, whereas exons 2, 3, 6 and 10 are alternative. Exon 3 never appears independently of exon 2. Exons 1 and 14 are present in the mRNA, but are never translated. Six main transcripts are present in the adult brain: $2-3-10-$ or $0 \mathrm{~N} 3 \mathrm{R} ; 2+3-10-$ or

by the multiplicity of tau inclusions and their molecular composition.

\section{Prion-like propagation hypothesis}

Tauopathies and other neurodegenerative disorders are reminiscent of prion diseases. The latter are indeed related to a pathological change (misfolding) in the molecular conformation of the normally present prion protein and to the capacity of misfolded prions to induce misfolding by contact
$1 \mathrm{~N} 3 \mathrm{R} ; 2+3+10-$ or $2 \mathrm{~N} 3 \mathrm{R} ; 2-3-10+$ or $0 \mathrm{~N} 4 \mathrm{R} ; 2+3-10+$ or $1 \mathrm{~N} 4 \mathrm{R} ; 2+3+10+$ or $2 \mathrm{~N} 4 \mathrm{R}$. b Tau structure. Four domains with different biochemical properties can be retrieved in tau protein: an acidic amino terminal region (corresponding to the expression of exons 1-5), a proline-rich domain (corresponding to the expression of exons 7 and 9), the MTBR with four repeated sequences (R1-R4), and a carboxy-terminal tail (exon 13). Modified from [28]

with a normally folded prion. Interestingly, different strains of prion exist with dissimilar fibre conformations that are transmissible [175]. There are at least two steps in the development of prion diseases: (1) misfolding induction and (2) transport of the misfolded prion that permits contact with still normal prions. Step 1 is called seeding, and step 2 is propagation. Propagation can take place by diffusion in the extracellular space or along the axonal paths.

Seeding and propagation have been reported not only with prions, but also with $A \beta$ [102] and alpha-synuclein [97]. The term "prion-like" has been attributed to this molecular 


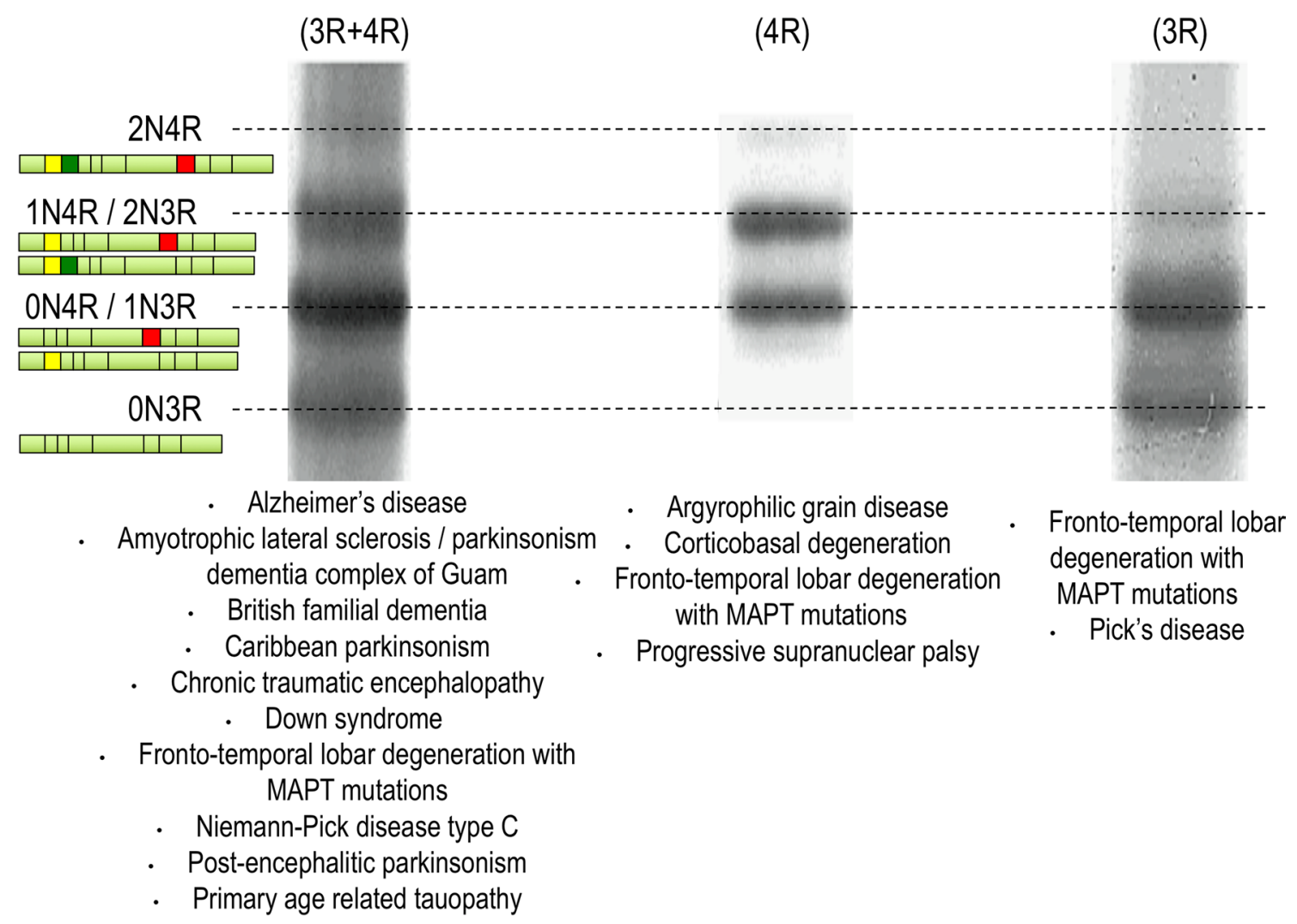

Fig. 2 Tauopathy 'barcode'. Western blots showing the electrophoretic profile observed with tau protein aggregates from patients with different tauopathies. In AD-like, the six tau isoforms are present in

behaviour when applied to proteins other than prions; such proteins have been called "propagons" and may induce protein misfolding in test-tubes, tissues, organisms or between subjects (infectious). Although there is no clear evidence of such interindividual transmission for tau, in several tauopathies, tau pathology progresses by well-defined "stages", which may support prion-like propagation. Here, the term "prion-like propagation hypothesis" includes the two steps: seeding and propagation.

\section{Pathology stages and the "propagation hypothesis" in humans}

In $\mathrm{AD}$, tauopathy is found sequentially in the transentorhinal-entorhinal areas, hippocampus and limbic areas and finally in the associative and then primary neocortical areas [20] (Fig. 4a). In PSP, the tauopathy is initially confined to the pallido-luyso-nigral system and then involves the basal ganglia, the pontine nuclei and the dentate nucleus, and finally the frontal and parietal lobes-with not only the extent but also the severity of the involvement increasing with time [181, 189] (Fig. 4b). In AGD, the tauopathy is initially limited to the ambient gyrus and its vicinity; it the aggregates. In PSP-like, only the 4R-tau proteins are aggregated. In Pick's disease, only the $3 \mathrm{R}$ isoforms are aggregating. Modified from [160]

involves secondarily the temporal pole, the subiculum and the entorhinal cortex and finally, the septum, insular cortex, and anterior cingulate gyrus [152] (Fig. 4c). In Pick disease, Pick bodies are initially seen in limbic regions; subcortical regions (the thalamus, striatum, locus coeruleus, raphe nuclei, dorsal motor nucleus of the vagus nerve, and reticular formation) as well as the primary sensory cortex are affected secondarily, followed by the primary motor cortex, the inferior olivary nucleus, and finally, the primary visual cortex [96] (Fig. 4d).

The active cell-to-cell transfer of tau has not yet been visualized in the human brain, even if some positron emission tomography (PET) and magnetic resonance imaging (MRI) studies suggest that it may occur. Similar to the Braak stages, there are strong arguments to support a hierarchical pathway of neurodegeneration along neural networks in $\mathrm{AD}$ [42, 48, 91].

The progression by stages in those tauopathies has suggested that two mechanisms, not necessarily antagonists, could be involved: progression of a pathogenic molecule along neuronal connections or selective vulnerability (pathoclisis). Given the complexity of the neuroanatomy of the central nervous system, the existence of connections between 


\section{a- Physiology}

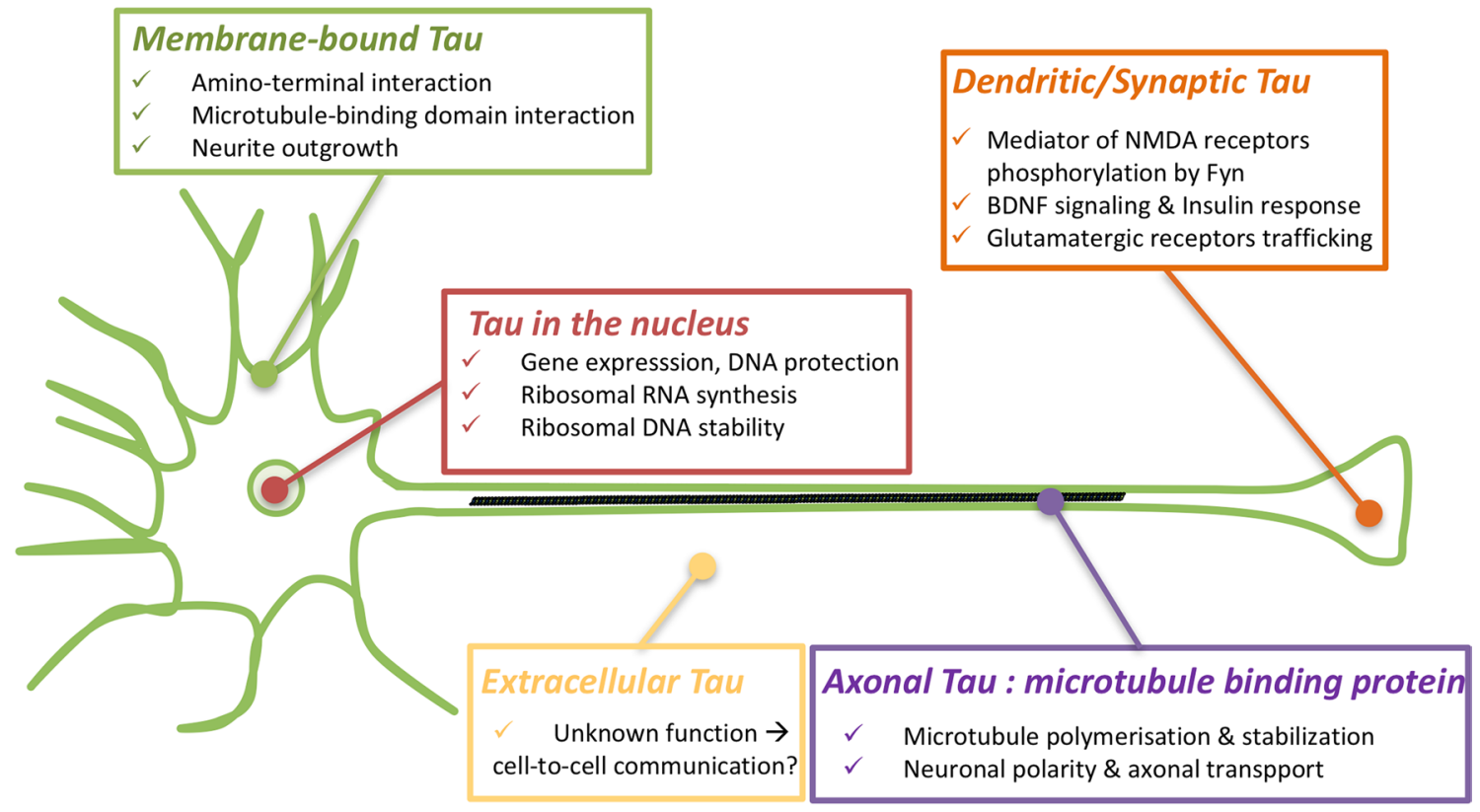

\section{b - Pathology}

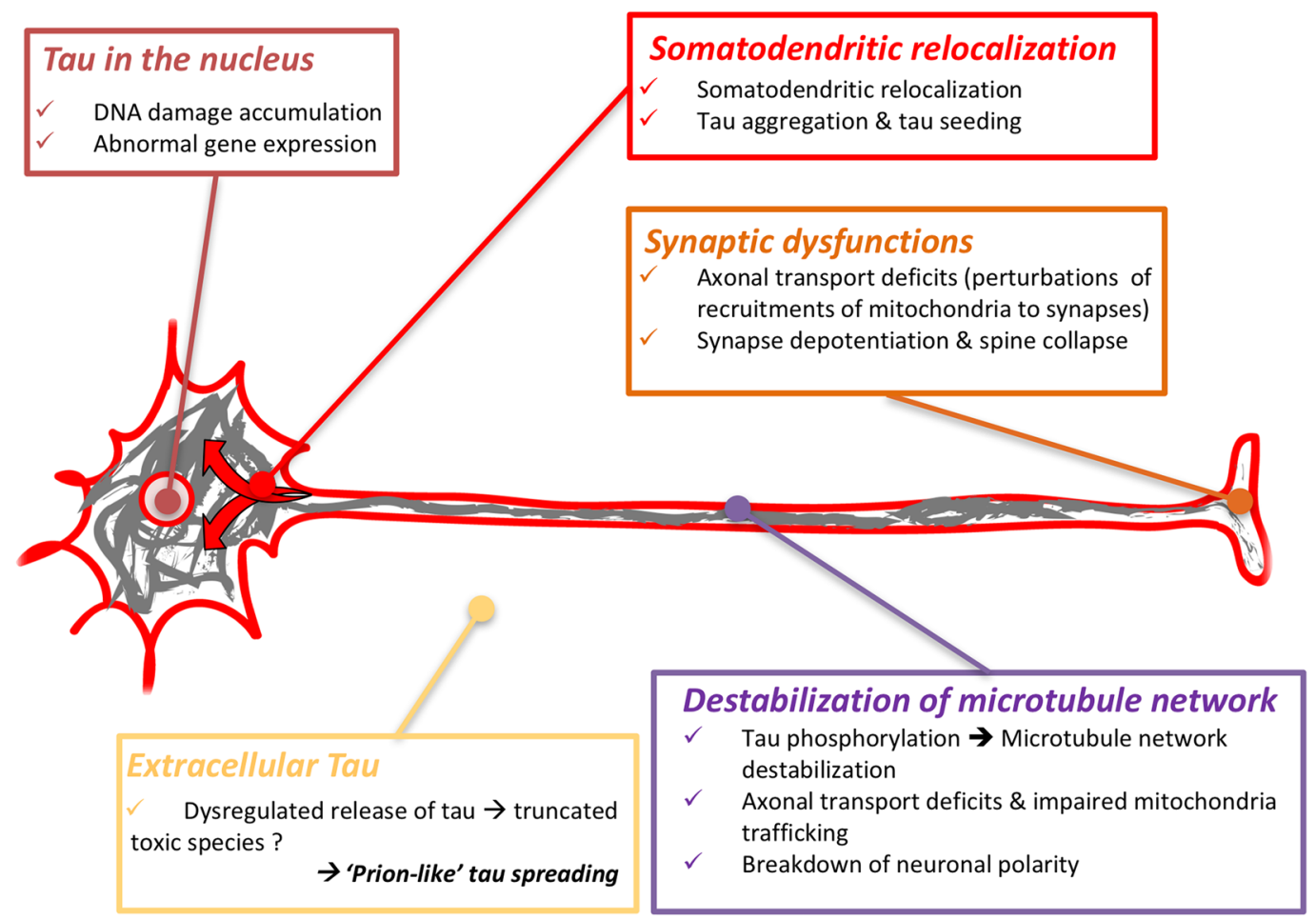

Fig. 3 Functions and dysfunctions of tau proteins a Physiologically, tau protein is mainly located in the cytoplasm of axons to stabilize the microtubules. Other minor locations of tau can be observed, such as in the nucleus [117], bound to the membranes [23] and in dendrites [99]. These locations are associated with atypical functions of tau [164], such as structuring chromatin and protecting nucleic acids from oxidative stress $[15,39,120,144,169,182,183]$, insulin signalling by binding to PTEN in the somato-dendritic compartment [121], mediating neuronal activity via the Fyn kinase and NMDA receptors in dendrites $[29,99,129]$. Tau proteins are also retrieved in extracellular fluids. b During tauopathies, tau proteins are excessively and abnormally phosphorylated and then aggregate, leading to a substantial loss of function. In particular, the microtubule network is destabilized, tau proteins are relocalized and synaptic deficits appear. Extracellular tau proteins are modified, and their functions are not completely understood even if they could participate in tau pathology propagation in the brain 
Fig. 4 a Staging of tau pathology in AD. Topographic distribution of tau lesions at the different stages of tau pathology in schemes of brains in medial views. Stages I and II, tau lesions invade entorhinal and transentorhinal regions. Stages III and IV: lesions involve the associative areas of the neocortex, and finally, during stages $\mathrm{V}$ and VI, tau lesions invade all the primary and secondary neocortical areas. From [22]. b Staging of tau pathology in PSP. Topographical distribution of tau lesions at the different neuropathological stages of PSP in schematic brain representations in medial views. Stages 0/I-Only the pallido-luyso-nigral complex shows tau pathology with weak involvement of the premotor cortex. Stage II/III-Tau pathology reaches the basal ganglia, pedunculopontine nucleus and dentate nucleus. Stages IV/V-Frontal and temporal lobes are involved. Stages VI/VII - Subthalamic nucleus, substantia nigra, internal globus pallidus, neocortical areas, pedunculopontine nucleus and cerebellum are more severely affected. Modified from [189]. c Staging of tau pathology in AGD. Topographical distribution of argyrophilic grains at the different stages of tau pathology evolution in three coronal sections. Stage I-argyrophilic grains are located in the ambiens gyrus, anterior CA1, anterior entorhinal area and amygdala. The stage II-medial temporal lobe is more affected by the involvement of the posterior subiculum, entorhinal and transentorhinal cortices. Stage III grains invade the anterior cingulate gyrus, septum, accumbens nucleus, rectus gyrus, insular cortex and hypothalamus. Modified from [152]. d Staging of tau pathology in Pick's disease (PiD). Topographical distribution of Pick bodies at the different stages of tau pathology evolution in schematic brain representations in medial views. Stage I Tau pathology is deposited in the limbic and neocortical frontotemporal regions as well as the angular gyrus. Stages II/ III-White matter tracts, subcortical structures, serotonergic/noradrenergic brainstem nuclei are affected, followed by the primary motor cortex and pre-cerebellar nuclei. Finally, in stage IV, tau is deposited in the visual cortex as well as in the cerebellar granular layer and brainstem white matter. Modified from [96]

two regions of the brain that are successively involved is a necessary condition, but not proof, of the progression along neuronal connections. On the other hand, the presence of tau pathology in astroglial cells cannot be directly explained by the connections. In fact, in PSP, at transcriptomic level, tufted astrocytes appear to be associated with a microglial gene-enriched immune network whereas neurofibrillary tangles would be linked to a brain co-expression network enriched for synaptic and PSP candidate risk genes [3]. Numerous uncertainties remain concerning the progression of the tauopathies and neurodegenerative diseases in general, which explains the current controversies [65, 113, 177].

Notably, the diversity of the tauopathies likely implies a diversity of pathogenic mechanisms. It appears implausible that one single treatment could apply to all of them. Conversely, a progression through connections like in $\mathrm{AD}$ would be compatible with a prion-like mechanism and thus it is fair to explore this hypothesis among tauopathies.

The most striking evidence of transmission of the pathology through connection is found in AD. Connectivity is explicitly implicated by Braak and Braak in the description of their stages [20]. In addition, an interesting autopsied AD case has also been reported showing that a 27 -year meningioma removal by neurosurgery had massively disconnected a - Alzheimer's disease

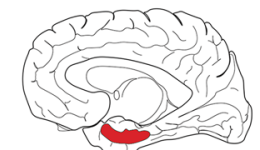

Stages |-||

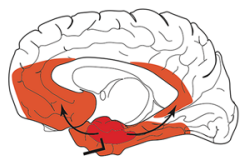

Stages III-IV

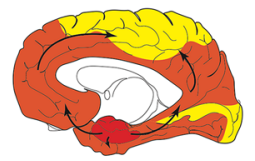

Stages V-VI b -Progressive supranuclear palsy

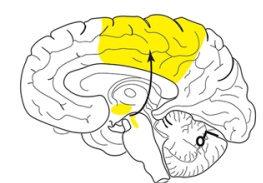

Stages 0-1

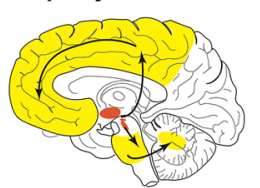

Stages IV-V

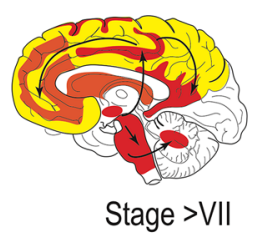

C-Argyrophylic Grain Disease
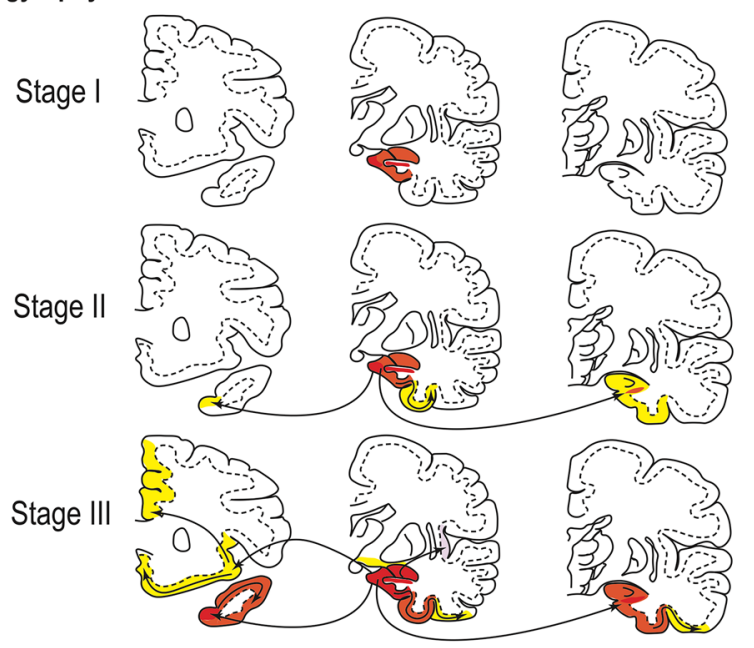

\section{d- Pick's Disease}
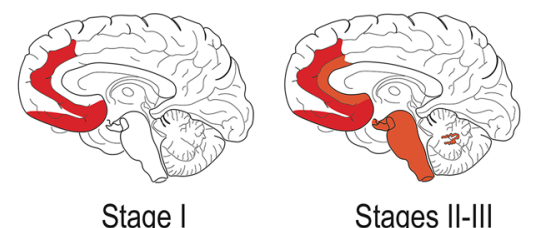

Stages II-III

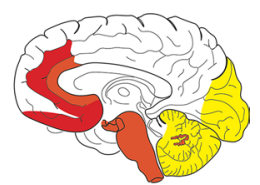

Stage IV

a piece of cortex. A local dissociation between neuritic and $\mathrm{A} \beta$ pathologies was seen. Neuropathological analyses fully confirmed AD diagnosis with numerous amyloid deposts and NFTs. However, in the disconnected cortical brain region where amyloid deposits were numerous, no neurofibrillary tangle was observed suggesting that their presence is determined by the neural connections [64].

However, other hypotheses have been proposed. According to one of them, AD would be a phylogenic neurodegenerative disease of higher primates following an evolutionary change in the primate genome [145]. According to another hypothesis, the pattern of neurodegeneration may be explained by the possible existence of chemically defined neuronal subpopulations that are highly vulnerable in $\mathrm{AD}$ [92]. In fact, this neurodegeneration pathway bears a striking 
resemblance to the inverse sequence of cortical myelination [19].

Recently, the hypothesis of prion-like propagation has offered an explanation for this hierarchical pathway of neurodegeneration [21]. The relevance of the widening of this concept is still being discussed. There is still controversy about tau propagation in CBD, Pick's disease and PSP [24, $48,59,73,96,137,181,189]$. The recent use of tau PET imaging will be helpful in bringing new insights into such debate [112].

\section{Human tau in peripheral fluids: a new argument for the prion-like propagation hypothesis?}

The propagation, included in the prion-like hypothesis, implies tau passage in the extracellular space. The passage of misfolded tau in the extracellular space could be passive and related to neuronal death. Currently, there is evidence that misfolded tau is actually secreted [194, 195]. As a consequence of the secretion step, tau is found in extracellular fluids (in a vesicular or non-vesicular form) [130, 140]. The interstitial fluid (ISF) that is found in the brain between the cells may be directly sampled and analysed by microdialysis. In humans, microdialysis has been used in cases of acute brain trauma to monitor brain metabolism [89], but the technique cannot be applied to neurodegenerative diseases such as tauopathies. Approximately, 20\% of the cerebrospinal fluid (CSF) originates from ISF [157]; changes in ISF protein concentrations are thus probably reflected by changes in the CSF. Tau proteins originating mainly from neurons have decreasing concentrations from ventricles $(320 \mathrm{pg} / \mathrm{mL})$ to lumbar subarachnoid space $(210 \mathrm{pg} / \mathrm{mL})$ [147]. This observation suggests that CSF tau originates mainly from ISF and CSF is the extracellular compartment closest to the brain, which is most accessible for sampling. CSF tau has been extensively studied to investigate the pathophysiological processes occurring in neurodegenerative diseases in living patients. The presence of tau in CSF was identified by electrophoresis in the mid-80s [37, 77] and quantified from 1993 by sandwich enzyme-linked immunosorbent assay [180]. Human CSF contains tau levels typically ranging from approximately 100 to $1200 \mathrm{pg} /$ $\mathrm{mL}$ [123]. Recently, CSF tau kinetics were quantified by stable isotope labelling kinetics (SILK) labelling in healthy individuals (half-life $=23 \pm 6.4$ days, tau production rate of $26.3 \mathrm{pg} / \mathrm{mL} /$ day \pm 9.2 and CSF level of $812.7 \pm 186 \mathrm{pg} / \mathrm{mL}$ ) [158]. Regarding CSF tau quantification in tauopathies, only individuals with $\mathrm{AD}$ clearly display increased tau concentrations in CSF [14].

Until very recently, tau could not be detected in the plasma, because of its very low concentration compared with that in CSF. Although protein transfer from ISF and CSF to blood is very low, and its mechanisms are not well known (efflux across the blood-brain barrier [11], along the glymphatic paravascular pathway [95], clearance through the dural lymphatic system in blood [139]). Tau levels in plasma might thus also be altered by changes in the brain [11] (Table 1).

Altogether, the prion-like propagation hypothesis is further supported by the increased and stable concentrations of extracellular tau in AD. In addition, recent work has shown that human CSF from AD patients is able to induce tau seeding in experimental models [163]. However, without a full characterization of tau species present in human ISF, it is hazardous to infer its concentration from that in CSF or in plasma. Animal models offer the possibility to recover ISF [192, 193].

\section{Modelling of the prion-like propagation}

Data from humans allowed the development of experimental models to assess whether the 'prion-like' propagation hypothesis is implicated in tauopathies and especially whether extracellular tau is relevant to this hypothesis. These models were thus designed to investigate the prion paradigm in regard to human neuropathology. For instance, with the upregulation of Rab7A in AD patients [78-80], tau secretion seems to be regulated by this small GTPase involved in the trafficking of endosomes, autophagosomes, and lysosomes [149]. Similarly, tau secretion is correlated with Golgi dynamics [128], consistent with its fragmentation noted in AD [167]. This hypothesis involves a multi-step mechanism (tau secretion, uptake and subsequent seeding processes) that has been widely explored.

\section{Tau secretion}

First, is it possible to identify a mechanism by which tau is found in peripheral fluids? The nature of secreted tau is debated in the literature $[130,141]$ (Fig. 5). Tau is secreted in a free form [60,103, 125, 185], but it is also found inside nanotubes [1,173] or associated with extracellular vesicles (EVs) [140]. Whereas nanotubes may be difficult to visualize in the human brain, secreted tau in EVs is found not only in experimental models but also in peripheral fluids (CSF $[153,185]$ and blood $[70,85,190])$ in AD patients. However, immunoassays in cell models revealed that whereas tau is mainly secreted in a free form in conditioned medium, only $10-20 \%$ of EVs contain tau [60, 185].

In this regard, tau is a cytosolic protein and does not follow the classical secretory pathway. It is translated into the cytosol, and the mechanisms modulating tau secretion are numerous and include tau oligomerization, tau truncation and mutations, tau interaction with plasma and organelle membranes and tau hyperphosphorylation [142]. For 


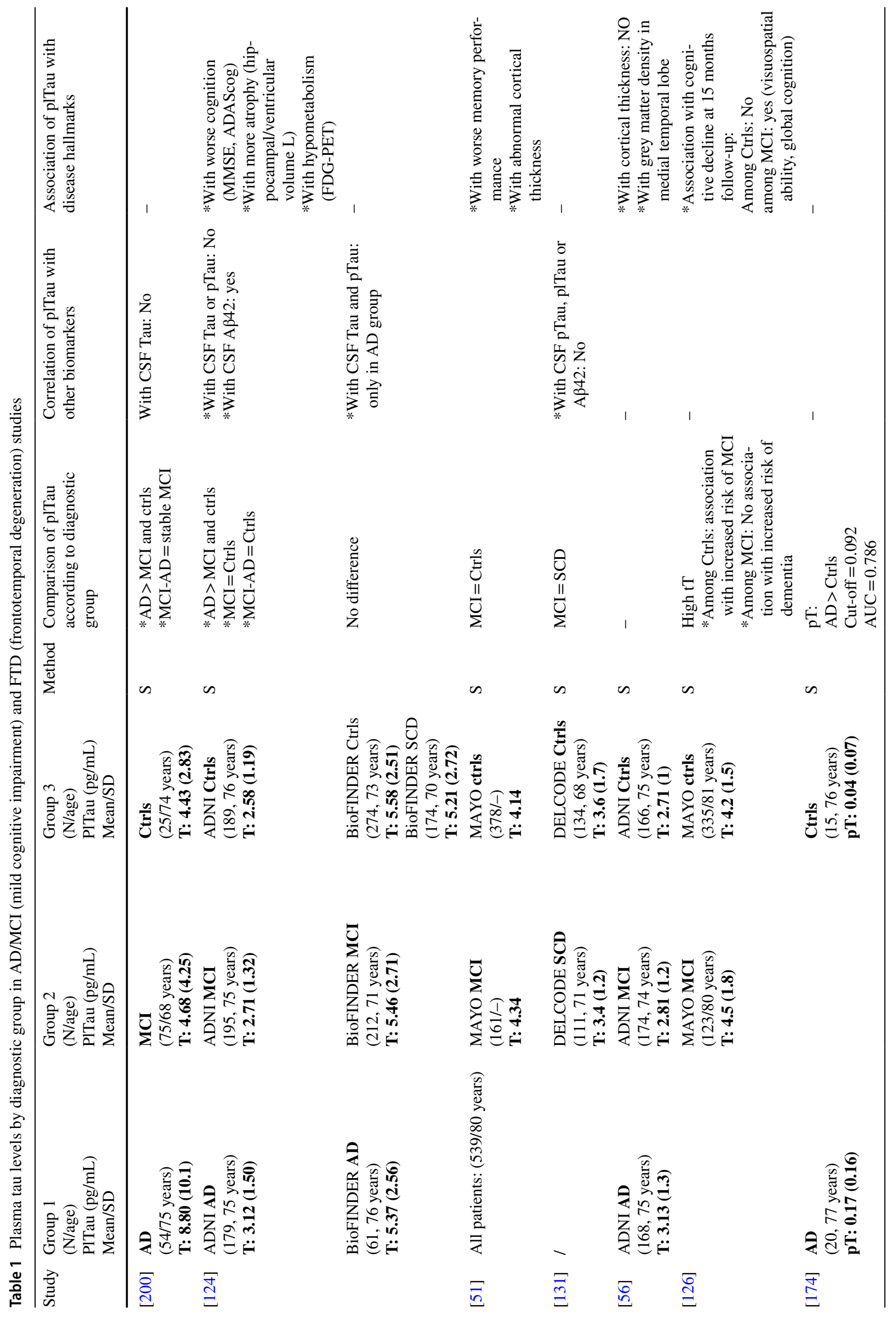




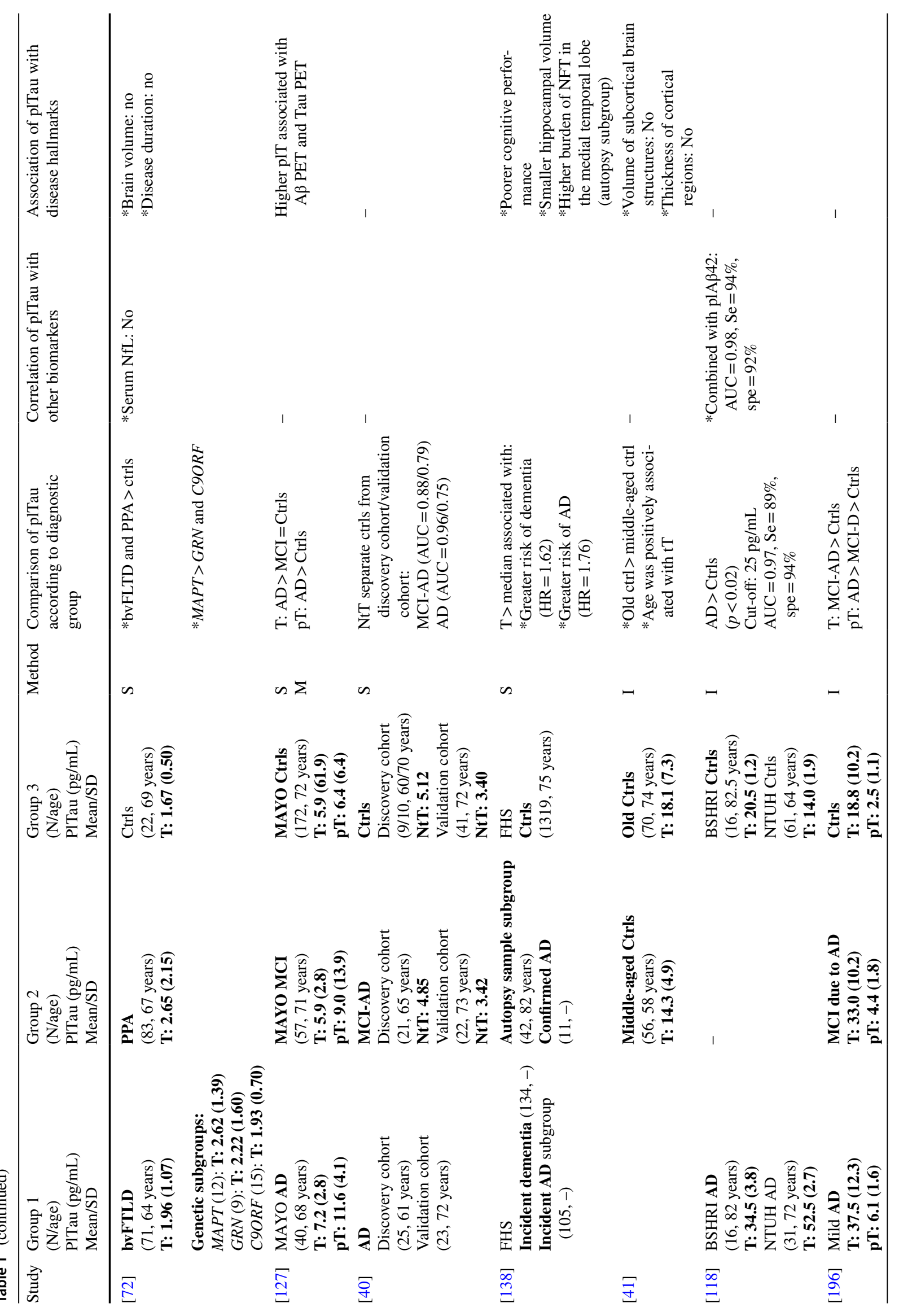




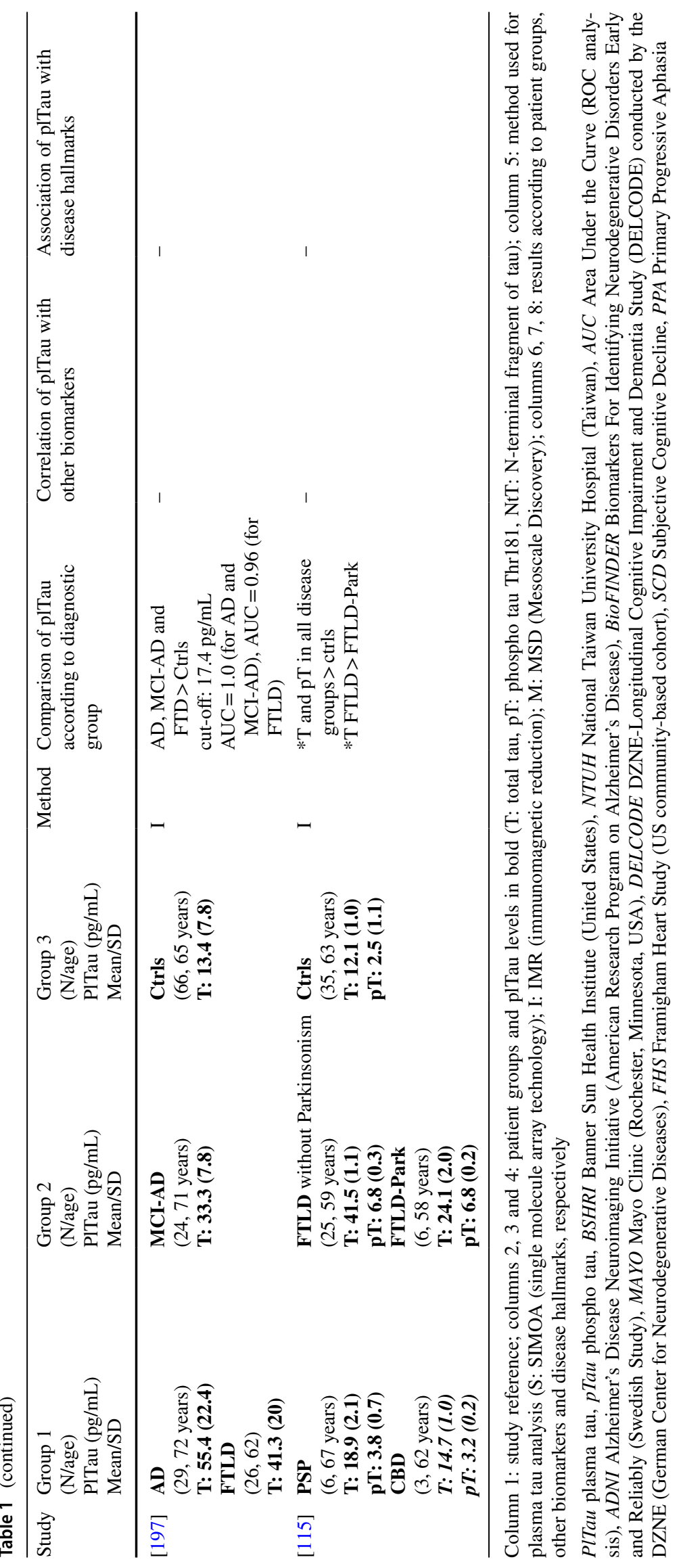




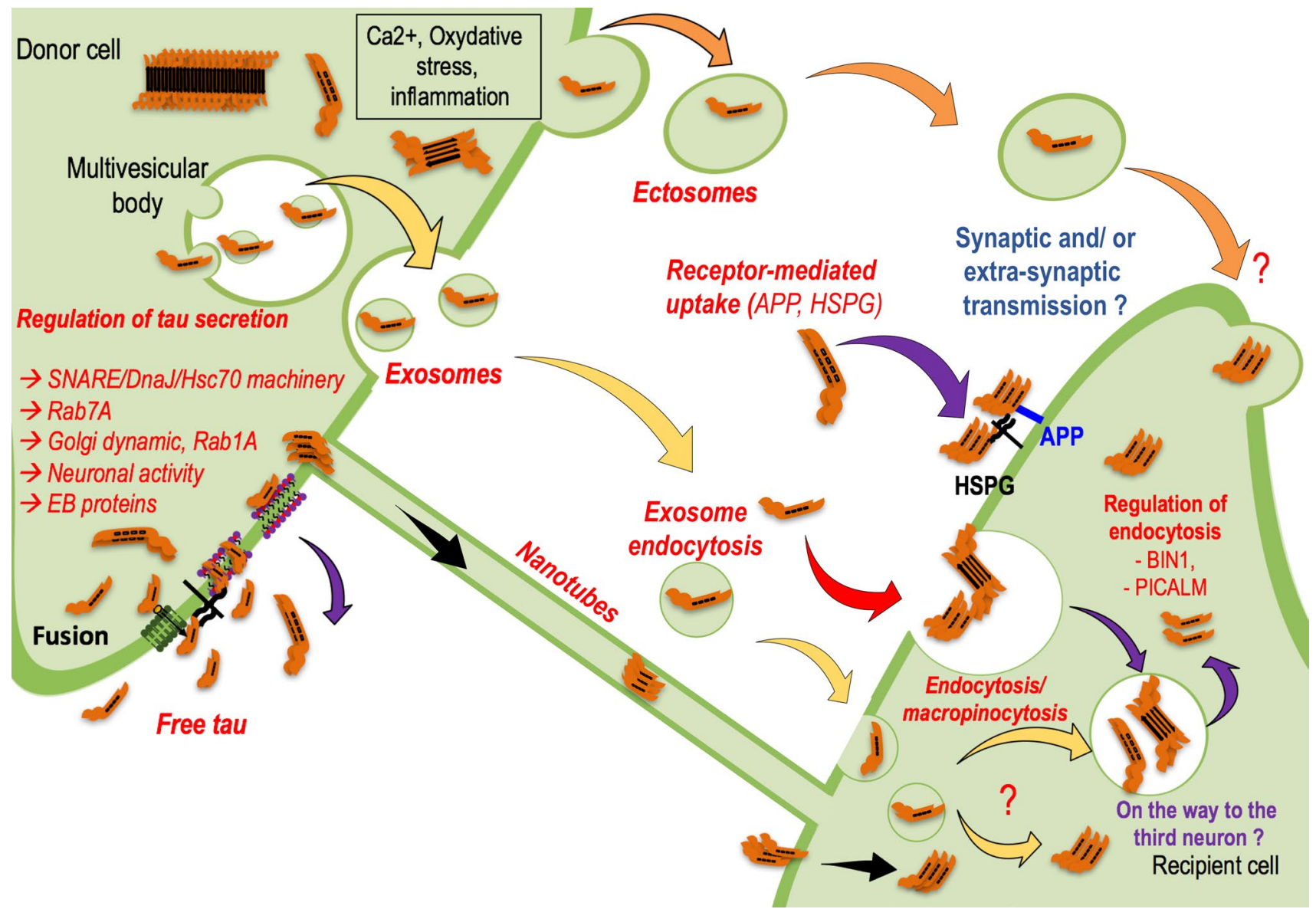

Fig. 5 How is tau secreted and transferred into recipient cells? Tau secretion-Yellow-Tau protein could be carried by EVs, and the most investigated proteins are the exosomes, which are small vesicles $(50$ $150 \mathrm{~nm}$ ) coming from a subpopulation of intraluminal multivesicular bodies vesicles. Orange-Tau protein could also be carried by larger EVs named ectosomes (150-1000 nm) coming from the direct budding of the plasma membrane. Ectosome budding is regulated at least by calcium and oxidative stress, which are deregulated in many neurodegenerative disorders. Violet-Finally, tau protein is mainly found in a free form in extracellular fluids. How tau is secreted is not well documented, but a few papers are now investigating this mechanism and its regulation. Regardless of the shuttles and depending on the models used, tau has been identified in many forms in the extracellular compartment, and to date, no one has been able to decipher the toxic/propagative forms. Are those secreted species cleared from the interstitial fluid? Are they transferred to other brain cells to propagate the pathology? Is this information implied in normal brain cell-to-cell communications? Tau transfer-How is tau taken up and handled by the receiving cells? Whether tau transfer requires the synapse remains

instance, non-conventional secretion of cytosolic proteins such as fibroblast-growth factor 2 (FGF-2) and interleukin $1 \beta$ (IL1 $\beta$ ) include oligomerization and truncation, respectively $[119,166]$. Similar to FGF-2, soluble hyperphosphorylated tau oligomers may directly translocate across the plasma membrane upon binding to $\mathrm{PI}(4.5) \mathrm{P}_{2}$, followed by retention on the cell surface through heparan sulfate proteoglycans (HSPG) [103, 125]. IL1ß secretion is also a matter of debate, and there is now some evidence that it might support the process. Nevertheless, the co-existence of the lateral transmission process should not be excluded. Black-Tau protein may move from cell to cell via nanotubes, membranous actin-rich structures that form between two cells inducing cytoplasmic and membrane exchanges. Yellow-to deliver tau, exosomes may be taken up by endocytosis in receiving cells. However, in this manner, the rest of the process is unclear. Is tau targeted to intracellular degradative compartments, such as lysosomes, to generate tau seeds that will in turn convert the non-pathological receiving cell into a pathological state? Is tau transferred to a third population due to the endosomal pathway? The exosomal transfer from the first to the third neurons via exosomes seems to be linked to the hijacking of secretory endosomes. The way ectosomes are taken up by receiving cells has not yet been investigated. Red-Tau proteins could also be internalized in the secondary neuron via an endocytosis mechanism. Such a process might be regulated by Bin1 and PICALM proteins, as both have been identified by GWAS as binding partners of tau

an interesting model for tau secretion. First, extrinsic factors, such as inflammation, are likely to modulate this nonconventional secretion. Additionally, a sequence containing human tau residues (amino acid 18 to amino acid 28) was recently shown to act as a binding motif for end binding proteins [159]. These proteins belong to the group of microtubule plus-end tracking proteins that have been implicated in the secretion of IL1 $\beta$ [184] and might also regulate tau 
secretion. The inflammasome may trigger a pathological cascade leading to enzyme activation, tau truncation and secretion. In human CSF, $99.9 \%$ of tau is truncated at the C-terminal domain, and major cleavage seems to occur around amino acids 210-230 [158]. This finding was confirmed by Cicognola and collaborators who described an important cleavage site at amino acid 224 [43]. In the presence of $A \beta$, such a mechanism may be exacerbated [158], supporting the prion-like propagation hypothesis in AD.

\section{Tau uptake/transfer}

In the propagation hypothesis, secreted tau must be taken up by cells (Fig. 5). In vivo models recapitulating pathological propagation have been developed. Focal intraneuronal expression of tau was obtained using either a neuropsin promoter $[55,116,187]$ or viral vectors $[6,30,59$, $60,186]$. Although both models show cell-to-cell transfer of tau, thorough controls are required to exclude transgene leakage [198], viral diffusion throughout the brain [63] or side-effects related to tau overexpression. Regarding this latter, the recent humanization of the murine MAPT gene clearly indicates that prion-like propagation occurs without overexpression [151]. Many other in vivo models investigating tau propagation are based on intracranial delivery of pathological material (recombinant oligomeric or fibrillar tau, human or mouse brain-derived material, etc.) [130] or peripheral administration [46] in transgenic and non-transgenic mice. These models bypass how tau is secreted from donor cells and focus on how tau is captured and lead to seeding in receiving cells. Some of these models suggest that over time, tau pathology appears in distant, synaptically connected areas, which suggests cell-to-cell propagation. However, the exact role of synapses in the tau propagation process remains under investigation, although seed competent tau was recently shown to be enriched in the synaptic fraction of AD brain-derived materials [57]. Nonetheless, we cannot exclude the possibility that the spread of tau pathology may occur via a number of pathways, including synaptic transfer, interstitial diffusion and even glial (astrocytes [109, 122], oligodendrocytes [132] and microglia [6]) intervention.

Many in vitro models have been developed to understand such uptake. Free aggregates present in the culture medium seem to be internalized via endocytosis $[66,75$, $86,93,106,143,156,191,194]$, and this uptake might be mediated by HSPGs [93, 146, 168, 188]. The extracellular region of APP also seems to be involved in the uptake of tau fibrils in neuroblastoma cell lines [170], but other more specific receptors are also likely implicated in these mechanisms. Two entry mechanisms were recently described: the monomer of tau uses a slow actin-dependent micropinocytosis pathway, whereas aggregated tau is taken up in a rapid way independent of actin polymerization but dependent on dynamin, consistent with an endocytosis process [66]. Bin1, a neuronal amphyphisin2 isoform that is downregulated in AD brains, inhibits endocytic activity and might be involved in the propagation of tau pathology [32]. The use of double or triple microfluidic chambers is informative for studying cell-to-cell transfer as it directly links the donor to the receiving neuronal populations, emphasizing the role of synapses in cell transfer [31, 63, 143, 171, 185].

Altogether, the hierarchical pathway of neurodegeneration in the prion-like propagation hypothesis strongly suggests a highly regulated mechanism allowing specific targeting of neuronal populations. In light of the available data, this selectivity is likely to rely on receptor-mediated endocytosis.

\section{Tau seeding}

The prion-like seeding implies that abnormal proteins can convert normal proteins into a pathological form. In this regard, Clavaguera and co-workers showed that injecting tau aggregates extracted from mice overexpressing mutated tau (P301S) into mice overexpressing human wild-type tau was sufficient to induce tau pathology [45]. When a tauimmunodepleted extract is injected, no pathology can be detected, showing that tau is the responsible factor as confirmed later by other groups [134, 179, 194]. However, this seeding activity may also require the presence of different co-factors such as polyanions $[58,201]$. The same group obtained similar results by injecting human brain lysates of different tauopathies and reproducing the specific morphology of the lesions seen in the human diseases [44], supporting the concept of propagons and tau strains.

In vitro, even if a few studies showed that extracellular tau may bind to neuronal receptors (muscarinic [83], $\mathrm{Na}^{+} /$ $\mathrm{K}^{+}$ATPase (NKA) [161]...) and have toxic effects, most have shown that incubated aggregates/seeds are internalized by endocytosis and promote aggregation of overexpressed tau in cell lines $[66,75,86,93,94,134,135,148,156$, 170-172]. Nevertheless, most seeding assays use transfection reagents and thus bypass receptor-mediated endocytosis, which may be a critical step in prion-like propagation. In this regard, are the propagons in a free form or membrane associated? It is known that exosomes containing tau with seeding activity have been isolated from the brains of tau transgenic mice [9]. In addition, seed-competent tau species, in both free and vesicular forms, have been detected in CSF and ISF from experimental models and CSF from AD patients [85, 171]. These studies imply that tau in EVs may be endocytosed and act as a seed and therefore contribute to prion-like propagation of tau pathology. Nonetheless, as 
indicated above, tau in EVs is minor and immunodepleted brain extracts does not exhibit any seeding competencies.

Following the work of Clavaguera and collaborators, many subsequent studies have shown that injections of cerebral lysates or synthetic tau fibres in transgenic mice potentiate transmissibility [130]. In such experiments, humanmutated tau seeds are already overexpressed in a murine tau model, and additional seeds are injected. These works further not only support tau seeding but also indicate that it happens outside of the strict prion definition. In any case, regardless of the seeds used (artificial or brain-derived), seeding is efficient and supports this step of the prion-like propagation hypothesis [130].

Collectively, with their strengths and weaknesses, all the data generated in experimental models have greatly strengthened the prion-like propagation hypothesis. In addition, in line with the prion-like propagation hypothesis and the identification of tau in the extracellular space, free extracellular tau species are now considered key drivers in the pathology propagation by the scientific community, making them attractive targets for therapeutic approaches.

\section{From experimental models to clinical trials}

Historically, tau therapeutic interventions were designed to target intraneuronal mechanisms such as modulating PTMs, breaking tau aggregates or decreasing tau concentrations [100]. Many of them have already failed and a global tau silencing may have side-effects due to multiple tau functions [100, 164]. More recently, tau immunotherapy showed promising preclinical results. While different mechanisms, such as microglial activation and the generation of different anti-tau antibodies, are involved in vaccination, we focus here on mechanisms involved in passive immunotherapy that have been widely explored in different experimental models $[2,7,17,33-35,47,50,52-54,155,176,178,179$, 194]. Early studies have shown that tau vaccination and tau immunotherapy could reduce intraneuronal tau pathology. Most of them decreased the amount of insoluble tau materials $[7,176,194]$. Cognitive decline was also reduced in some [176, 194], including those using MC1, an antibody recognizing a conformational epitope involving the amino terminus of tau [101] and HJ8.5, an antibody recognizing the amino acids 25-30. Both have been further developed for human immunotherapy and are now in clinical trials (LY3303560, ABBV 8E12-Table 2). Peripheral administration of this MC1 antibody in murine models of tauopathy has not only reduced tau pathology quantified by biochemical and immunohistochemical analyses but also delayed the onset of decreased motor impairment and weight loss [35]. Such experiments were also performed with a phosphodependent antibody (anti-pS422, also further developed for human immunotherapy, RG7345-Table 2) showing similar effects with the involvement of the endosome-lysosome pathway [47]. The finding of tau secretion and its compatibility with the prion-like propagation hypothesis have modified the strategy of immune therapy: research was then oriented towards antibodies that did not penetrate the cells and principally acted in the extracellular space.

The Fc part of immunoglobulins $\mathrm{G}$ (IgGs) binds to specific Fc gamma receptors ( $\mathrm{Fc} \gamma \mathrm{R})$, which are variously expressed in neurons, microglia or astrocytes. Different classes of $\mathrm{Fc} \gamma \mathrm{R}$ have been described with high affinity (binding to monomeric IgG complexes) or low affinity (binding only to multimeric $\mathrm{IgG}$ complexes) to different Fc. Microglial cells highly express all classes of Fc $\gamma \mathrm{R}$ [4], whereas only Fc $\gamma$ RI has been reported in astrocytes. In neurons, the expression of Fc $\gamma \mathrm{R}$ is still debated [136], but neurons [69] and microglia [4] seem to upregulate Fc $\gamma \mathrm{R}$ in response to extracellular $\mathrm{IgG}$ with a functional $\mathrm{Fc}$ domain.

The different isotypes of human $\operatorname{IgG}(\operatorname{IgG} 1, \operatorname{IgG} 2, \operatorname{IgG} 3$ and $\mathrm{IgG} 4$ ) have, on the other hand, different affinities for the receptors. For example, human IgG1 has a higher affinity for activating $\mathrm{Fc} \gamma \mathrm{Rs}$ present on microglia compared to human IgG4 and may induce a more pro-inflammatory response [26]. IgG4 may thus theoretically bind to its antigen, lowering its toxicity, while at the same time, limiting its cell internalization through $\mathrm{Fc}$ receptors and the potential inflammation, it may induce [111]. Most tau antibodies currently being tested in clinical trials use this isotype to target extracellular tau (Table 2). Nevertheless, most of the preliminary studies are performed in mice, and it is often difficult to translate these data to humans. In mice, four classes are also found, but they do not correspond to human IgG. In fact, murine $\mathrm{IgG} 1$ is closer to human $\mathrm{IgG} 4$ than murine $\mathrm{IgG} 2$. Thus, when murine antibodies and their effector functions are tested in animal models, it is always difficult to draw conclusions. For instance, Funk and collaborators showed that the murine version of ABBV 8E12 (HJ8.5 IgG2a) drives uptake of tau species into BV2 microglial cells [76]. However, single-chain HJ8.5 antibodies without Fc fragment (scFvs) significantly reduced levels of hyperphosphorylated, aggregated tau in brain tissue of tau transgenic mice [98]. Such data suggest that the Fc fragment may not be required for the efficacy of this family of anti-tau antibodies in tau immunotherapy. The use of different approaches and different models may thus sometimes lead to different conclusions on the impact of $\mathrm{Fc}$ fragment and receptor.

The most widely accepted scenario is that therapeutic antibodies bind extracellular pathological tau species in the ISF responsible for the spread of pathology but are not necessarily required to directly bind intraneuronal tau. The antibodies would block the seeding activity of extracellular tau, most likely by blocking the initial uptake of these seeds and slowing down the spread of pathology [134]. Nevertheless, 
Table 2 Clinical trials for tau immunotherapy: to facilitate the reading, the name of antibodies currently tested in clinical trials are given, but it should be kept in mind that their murine versions have been used in experimental models to assess their mode of action

\begin{tabular}{|c|c|c|c|c|c|c|}
\hline Antibodies & Isotype & Epitope & Mode of action & Target population & $\begin{array}{l}\text { Clini- } \\
\text { cal trial } \\
\text { phase }\end{array}$ & $\begin{array}{l}\text { Clinical Trials.gov } \\
\text { Identifier }\end{array}$ \\
\hline $\begin{array}{l}\text { BIIB076 (6C5)- } \\
\text { Biogen }\end{array}$ & IgG1 & & $\begin{array}{l}\text { Reduction in tau } \\
\text { uptake and cell } \\
\text { transfer }[84,134]\end{array}$ & $\begin{array}{l}\text { Healthy controls Mild } \\
\text { AD }\end{array}$ & $1 / 2$ & NCT03056729 \\
\hline $\begin{array}{l}\text { BIIB092 (IPN002)- } \\
\text { biogen }\end{array}$ & IgG4 & $\mathrm{N}$-terminus & $\begin{array}{l}\text { Binding eTau: reduc- } \\
\text { tion in neuronal } \\
\text { activation \& Aß } \\
\text { secretion [25] }\end{array}$ & $\begin{array}{l}\text { AD } \\
\text { PSP } \\
\text { Tauopathies }\end{array}$ & $1 / 2$ & $\begin{array}{l}\text { NCT03352557 } \\
\text { NCT02460094 } \\
\text { NCT03068468 } \\
\text { NCT03658135 }\end{array}$ \\
\hline $\begin{array}{l}\text { ABBV 8E12 (HJ8.5)- } \\
\text { abbvie }\end{array}$ & $\mathrm{IgG} 4$ & $\mathrm{~N}$-terminus & $\begin{array}{l}\text { Reduction in tau } \\
\text { pathology [76, 98, } \\
\text { 194] }\end{array}$ & $\begin{array}{l}\text { PSP } \\
\text { AD }\end{array}$ & $1 / 2$ & $\begin{array}{l}\text { NCT02985879 } \\
\text { NCT03712787 } \\
\text { NCT02880956 }\end{array}$ \\
\hline $\begin{array}{l}\text { JNJ-63733657-john- } \\
\text { son \& johnson }\end{array}$ & & $\mathrm{pS} 217$ & $\begin{array}{l}\text { Reduction in tau seed- } \\
\text { ing [150] }\end{array}$ & & 1 & NCT03375697 \\
\hline $\begin{array}{l}\text { LY3303560B (MC1) } \\
\text { lilly }\end{array}$ & & $\begin{array}{l}\text { N-terminus + confor- } \\
\text { mation [aa7-9 and } \\
\text { 312-34] }\end{array}$ & $\begin{array}{r}\text { Reduction in tau } \\
\text { pathology [35] }\end{array}$ & $\begin{array}{l}\text { Healthy controls } \\
\text { Mild/early AD }\end{array}$ & $1 / 2$ & $\begin{array}{l}\text { NCT02754830 } \\
\text { NCT03019536 } \\
\text { NCT03518073 }\end{array}$ \\
\hline $\begin{array}{l}\text { RG7345 (anti- } \\
\text { pS422)-Roche }\end{array}$ & N/A & pS422 & $\begin{array}{r}\text { Reduction in tau } \\
\text { pathology [47] }\end{array}$ & $\begin{array}{l}\text { Healthy controls Dis- } \\
\text { continued develop- } \\
\text { ment }\end{array}$ & 1 & $\begin{array}{l}\text { NCT02281786 } \\
\text { (RO6926496) }\end{array}$ \\
\hline RO7105705-Roche & IgG4 & $\mathrm{N}$-terminus & $\begin{array}{c}\text { Reduction in tau } \\
\text { pathology [8] }\end{array}$ & $\begin{array}{l}\text { Healthy controls Mild } \\
\text { AD }\end{array}$ & $1 / 2$ & $\begin{array}{l}\text { NCT02820896 } \\
\text { NCT03289143 } \\
\text { NCT03828747 }\end{array}$ \\
\hline $\begin{array}{l}\text { UCB0107 (antibody } \\
\text { D)-UCb Biopharma }\end{array}$ & $\mathrm{IgG} 4$ & $\begin{array}{l}\text { Mid- region close to } \\
\text { MTBR }\end{array}$ & $\begin{array}{l}\text { Reduction in uptake, } \\
\text { cell transfer and } \\
\text { seeding }[2,49]\end{array}$ & Healthy controls & 1 & NCT03464227 \\
\hline
\end{tabular}

The most advanced clinical trials (phases 1 and 2) include vaccination (AADvac1 and ACI-35, not shown) and passive immunotherapy (BIIB076, BIIB092 (Gosuranemab), ABBV-8E12 (Tilavonemab), JNJ-63733657, LY3303560 (Zagotenemab), RO7105705, UCB0107) and Lu-AF87908.

the future of such anti-tau antibody-tau complexes and their clearance are still puzzling, and many hypotheses have been proposed, as summarized in Fig. 6.

Therapeutic antibodies currently in clinical development have shown their capability to target extracellular tau (by modulating cell-to-cell tau transfer) and/or to reduce tau seeding in experimental models. The murine version of BIIB076 has been shown to block neuronal uptake of human tau species in microfluidic chambers [134]. BIIB076 was described to be more efficient in blocking tau uptake than an antibody directed against the C-terminus of tau protein [134]. The murine version of UCB0107 (binding a region before the first MTBR) displayed superior efficacy in an in vitro model of seeding and aggregation induced by human AD tau than antibodies targeting N-terminal, pS202/ pT205, or pS422 conformational epitopes [49]. It also effectively prevented the induction of tau pathology in the brain of transgenic mice injected with human AD brain extracts, in contrast to an amino-terminal tau antibody recognizing the same epitope as BIIB092 [2]. Other antibodies have also been tested by Vandermeeren and collaborators from Janssen [179]. Immunodepletion assays strongly suggest that difference exist between epitopes. In fact, antibodies that recognized the mild-region of tau are most effective while N-terminal antibodies could not fully block seeding in vitro (FRET assays) as well as in vivo (AD brain material enriched for PHFs injected into the hippocampus of P301L transgenic tau mouse to spur fibrillization immunized by various antibodies). Together, these results suggest that the murine version of JNJ-63733657 which is targeting the pS217, a central part of tau may also act in this way [107, 150]. Extracellular tau may also lead to neuronal hyperactivity and facilitate $\mathrm{A} B$ peptide secretion; in this paradigm, it was reported that the murine version of BIIB092, IPN002, is protective by blocking extracellular tau [25].

Finally, all these antibodies have shown some effects in mouse models, although few reports are available in humans. The next challenge is to validate the target engagement and efficacy of drug candidates.

Some studies on transgenic models suggest that plasma tau is a potential biomarker for therapeutic monitoring. Indeed, the active immunization of tau transgenic mice with peptides containing a pathological phosphorylated epitope (pS422) reduced pathological tau species in the brain and 


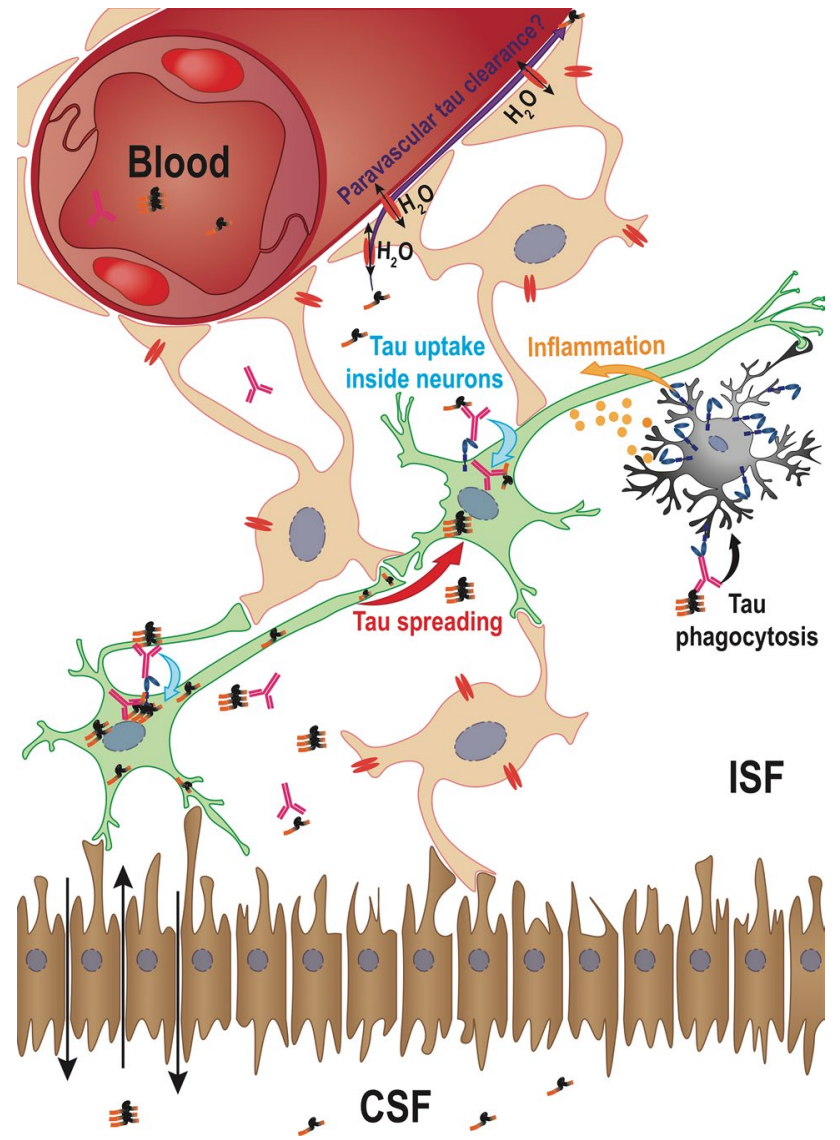

Fig. 6 Tau clearance mechanisms-The potential for targeting extracellular tau from ISF to prevent tau pathology spreading led researchers to investigate how antibodies might be able to clear tau from the brain. Very few data are available, but among them, three major hypotheses have emerged. (1) Internalization inside neurons (blue arrow)-The first mechanism that has been described is the endocytosis of tau-Ab complexes inside neurons after binding to Fc $\gamma$ RII/III, which might target tau to lysosomes for intracellular degradation. This degradation might amplify the propagation process by generating news seeds (red arrow). (2) Phagocytosis inside microglia (black arrow)-This second hypothesis is related to the microglial activity in the brain that might phagocytose tau and degrade it. This mode of action might be very deleterious for neighbouring neurons as the microglial phagocytosis process will generate a strong inflammatory response (yellow arrow). (3) Internalization inside astrocytes: the glymphatic tau clearance hypothesis (purple arrow). The ability of the brain to clear tau from ISF without the help of neurons and microglia is the more recent hypothesis. In this system, tau is cleared using the CSF flow through the water channel aquaporin 4 that is expressed on astrocytes and cells connected to the blood and CSF circulation via their basal ends

delayed cognitive deficits but was importantly associated with a significant increase in plasma tau concentrations [176]. Similarly, it was reported at the 2017 AD/PD conference that injection of RO7105705 in tau transgenic mice (13 weeks treatment $/ 3-30 \mathrm{mg} / \mathrm{kg}$ ) increased plasma tau [8]. This concept of tau/Ab complex stabilization in the plasma has also been validated by another study demonstrating that peripheral administration of the anti-tau antibody HJ8.5 (ABBV 8E12) increased plasma tau not only in transgenic mice, but also in PSP patients [195]. Such stabilization in plasma may be explained by high plasma concentrations of therapeutic antibodies. For instance, at the $2017 \mathrm{AD} / \mathrm{PD}$ and AAIC conferences, it was shown that BIIB076 concentrations were 1000-fold higher in plasma than in CSF when a single injection was administered in blood in cynomolgus monkeys [84]. Tau analysis is also performed in CSF in clinical trials and may help to show target engagement. For instance, the BIIB092 antibody in a phase 1b clinical trial in PSP is well tolerated, and its complex with tau is found in CSF [18]. In fact, most of the antibodies described in Table 2 are in clinical trials, and their outcome should be published in the months to come. Nevertheless, we know that the ABBV 8E12 antibody has already been discontinued in a phase 2 clinical trial in PSP. However, it is still ongoing in AD clinical trials. BIIB092, RO7105705 and ABBV 8E12 target the amino terminal domain of tau proteins, whereas UCB0107 recognizes an epitope in the mid-region before the repeats. Only JNJ-63733657 [107] and LY3303560B [35] target so-called pathological intracellular epitopes. Knowing the molecular diversity of tau species among tauopathies, do we have the right tool for the right disease? In fact, the main question is to define which species have seeding- and propagative-competent properties.

\section{Tau diversity in brain and biological fluids}

Since it is now acknowledged that extracellular tau (eTau) is a therapeutic target, the next generation of antibodies has to take into account the heterogeneity of tau species. This heterogeneity exists at the level of protein composition (tau sequence and PTMs), compartment (free or vesicular) and seeding competency. In fact, high heterogeneity of aggregated tau species is encountered in the human brain among tauopathies, and some of them may be released in ISF/CSF. As revealed by $2 \mathrm{D}$ electrophoresis studies, the tau proteome in CSF is at least as complex as that in the AD autopsy brain [88]. The pattern is composed of tau proteolytic fragments $[16,162,199]$. Barthelemy and collaborators $[13,14]$ identified peptides in the CSF of AD where they are abundant but also in the CSF of PSP, Lewy body dementia (LBD) and control groups where tau concentrations are very low. Among the identified peptides, those with the central part of tau (amino acids 126-234) were the most abundant ones, 4R-specific MTBR peptides were below the lower limit of detection, and the $2 \mathrm{~N}$ peptides were poorly detected, which might suggest that the $1 \mathrm{~N} 3 \mathrm{R}$ isoform is the most abundant isoform in CSF. When comparing pathologies, the central peptides (amino acids 126-234) were more abundant in the AD group than in the control, PSP and LBD groups. 
Nonetheless, no difference was observed between the PSP and LBD groups. The same observation was made by Cicognola and collaborators who described an important cleavage site at amino acid 224, especially in CSF from AD in comparison to MCI-AD, PSP and CBS [43].

The characterization of the species and nature of human tau species with seeding properties is a crucial, unanswered question. Are these seeds hypo- or hyperphosphorylated, truncated, or fibrillar? Recent studies looking precisely at seeding-competent tau from human brains with different tauopathies confirmed this molecular diversity in in vitro and in vivo models [44, 104, 105, 132, 154]. As described earlier, tauopathies are heterogeneous and there are some differences among tauopathies but we have to be aware that it is also true within a tauopathy. For instance, very little is known about the case-by-case molecular heterogeneity among a specific tauopathy such as AD and how such heterogeneity would affect the underlying pathophysiological mechanisms such as tau propagation and seeding. In this regard, Brad Hyman group described huge differences among seed-competency of human AD brain inoculates [62]. It does not mean that seeding models are bad, it only means that tau seeds in brain inoculates may be different among samples. It is not surprizing since the clinical course, the disease duration, the postmortem delay and maybe the storage conditions are different. It is important to be aware of this when seeding models are used to test and validate immunological tools. This last section highlights heterogeneity among tauopathies and strongly suggests that each disease may have its propagons. Thus, an anti-tau immunotherapy strategy common to all tauopathies is therefore unlikely.

\section{Conclusions}

If we want to summarize our knowledge, we can say that among tauopathies, the work of neuropathologists has made it possible to define specific neurodegenerative pathways suggesting the existence of vulnerable neuronal subpopulations for each disorder. These hierarchical pathways of tau pathology led to the hypothesis of prion-like propagation, which is based on human neuropathology and numerous experimental models and has led to the identification of a new player in tauopathies: eTau. This hypothesis has led to a reorientation of anti-tau therapeutic approaches, particularly immunotherapy. The main remaining questions are around molecular species responsible for propagation or seeding and their targeting by our therapeutic strategies. Do we have the right immunological tools?

However, we should not forget that the prion-like tau propagation hypothesis is still an assumption that is not unanimous. There are first very heterogeneous tau aggregates at the molecular and cellular level among tauopathies.
The diversity of neuronal populations and their connectivity are probably an explanation for differences among tauopathies. In any case, as we have seen, the arguments that support the prion-like propagation hypothesis in humans are particularly well documented in AD: the steadiness of Braak stages in $\mathrm{AD}$ patients and the high and constant concentration of eTau during $\mathrm{AD}$ pathology compared to other tauopathies. Thus, based on our current knowledge, AD is the best target for anti-eTau immunotherapy. With a remaining question, do we have the right approach since the prion-like propagation is still a hypothesis, like the amyloid cascade...

Acknowledgements This work was supported by grants from UCB Biopharma SPRL, the program Investissement d'avenir LabEx (laboratory excellence) DISTALZ (Development of Innovative Strategies for a Transdisciplinary approach to Alzheimer's disease) and ANR grants GRAND, SPREADTAU and TONIC (Grant no. ANR-14-CE13-0031). Our laboratories are also supported by LiCEND (Lille Centre of Excellence in Neurodegenerative Disorders), CNRS, Inserm, Métropole Européenne de Lille, Univ. Lille, FEDER and DN2M.

Open Access This article is distributed under the terms of the Creative Commons Attribution 4.0 International License (http://creativeco mmons.org/licenses/by/4.0/), which permits unrestricted use, distribution, and reproduction in any medium, provided you give appropriate credit to the original author(s) and the source, provide a link to the Creative Commons license, and indicate if changes were made.

\section{References}

1. Abounit S, Wu JW, Duff K, Victoria GS, Zurzolo C (2016) Tunneling nanotubes: a possible highway in the spreading of tau and other prion-like proteins in neurodegenerative diseases. Prion 10:344-351. https://doi.org/10.1080/19336896.2016.1223003

2. Albert M, Mairet-Coello G, Danis C, Lieger S, Caillierez R, Carrier S et al (2019) Prevention of tau seeding and propagation by immunotherapy with a central tau epitope antibody. Brain 142:1736-1750. https://doi.org/10.1093/brain/awz100

3. Allen M, Wang X, Serie DJ, Strickland SL, Burgess JD, Koga S et al (2018) Divergent brain gene expression patterns associate with distinct cell-specific tau neuropathology traits in progressive supranuclear palsy. Acta Neuropathol 136:709-727. https://doi. org/10.1007/s00401-018-1900-5

4. Andersson CR, Falsig J, Stavenhagen JB, Christensen S, Kartberg F, Rosenqvist N et al (2019) Antibody-mediated clearance of tau in primary mouse microglial cultures requires Fcgammareceptor binding and functional lysosomes. Sci Rep 9:4658. https ://doi.org/10.1038/s41598-019-41105-4

5. Andreadis A (2005) Tau gene alternative splicing: expression patterns, regulation and modulation of function in normal brain and neurodegenerative diseases. Biochim Biophys Acta 1739:91103. https://doi.org/10.1016/j.bbadis.2004.08.010

6. Asai H, Ikezu S, Tsunoda S, Medalla M, Luebke J, Haydar T et al (2015) Depletion of microglia and inhibition of exosome synthesis halt tau propagation. Nat Neurosci 18:1584-1593. https ://doi.org/10.1038/nn.4132

7. Asuni AA, Boutajangout A, Quartermain D, Sigurdsson EM (2007) Immunotherapy targeting pathological tau conformers in a tangle mouse model reduces brain pathology with associated 
functional improvements. J Neurosci 27:9115-9129. https://doi. org/10.1523/JNEUROSCI.2361-07.2007

8. Ayalon G (2017) Preclinical, characterization, efficacy, pharmacokinetics and pharmacodynamics and safety of RO7105705-An anti-tau antibody currently in clinical development for Alzheimer disease. In: AD/PD 2017-the 13th international conference on Alzheimer's and Parkinson's disease

9. Baker S, Polanco JC, Gotz J (2016) Extracellular vesicles containing P301L mutant tau accelerate pathological tau phosphorylation and oligomer formation but do not seed mature neurofibrillary tangles in ALZ17 mice. J Alzheimers Dis 54:1207-1217. https://doi.org/10.3233/JAD-160371

10. Bancher C, Brunner C, Lassmann H, Budka H, Jellinger K, Wiche $G$ et al (1989) Accumulation of abnormally phosphorylated tau precedes the formation of neurofibrillary tangles in Alzheimer's disease. Brain Res 477:90-99. https://doi. org/10.1016/0006-8993(89)91396-6

11. Banks WA, Kovac A, Majerova P, Bullock KM, Shi M, Zhang J (2017) Tau proteins cross the blood-brain barrier. J Alzheimers Dis 55:411-419. https://doi.org/10.3233/JAD-160542

12. Barghorn S, Zheng-Fischhofer Q, Ackmann M, Biernat J, von Bergen M, Mandelkow EM et al (2000) Structure, microtubule interactions, and paired helical filament aggregation by tau mutants of frontotemporal dementias. Biochemistry 39:1171411721. https://doi.org/10.1021/bi000850r

13. Barthelemy NR, Fenaille F, Hirtz C, Sergeant N, SchraenMaschke S, Vialaret J et al (2016) Tau protein quantification in human cerebrospinal fluid by targeted mass spectrometry at high sequence coverage provides insights into its primary structure heterogeneity. J Proteome Res 15:667-676. https://doi. org/10.1021/acs.jproteome.5b01001

14. Barthelemy NR, Gabelle A, Hirtz C, Fenaille F, Sergeant N, Schraen-Maschke S et al (2016) Differential mass spectrometry profiles of tau protein in the cerebrospinal fluid of patients with Alzheimer's disease, progressive supranuclear palsy, and dementia with lewy bodies. J Alzheimers Dis 51:1033-1043. https:// doi.org/10.3233/JAD-150962

15. Benhelli-Mokrani H, Mansuroglu Z, Chauderlier A, Albaud B, Gentien D, Sommer S et al (2018) Genome-wide identification of genic and intergenic neuronal DNA regions bound by Tau protein under physiological and stress conditions. Nucleic Acids Res 46:11405-11422. https://doi.org/10.1093/nar/gky929

16. Borroni B, Gardoni F, Parnetti L, Magno L, Malinverno M, Saggese E et al (2009) Pattern of Tau forms in CSF is altered in progressive supranuclear palsy. Neurobiol Aging 30:34-40. https ://doi.org/10.1016/j.neurobiolaging.2007.05.009

17. Boutajangout A, Ingadottir J, Davies P, Sigurdsson EM (2011) Passive immunization targeting pathological phospho-tau protein in a mouse model reduces functional decline and clears tau aggregates from the brain. J Neurochem 118:658-667. https:// doi.org/10.1111/j.1471-4159.2011.07337.x

18. Boxer AL, Qureshi I, Ahlijanian M, Grundman M, Golbe LI, Litvan I et al (2019) Safety of the tau-directed monoclonal antibody BIIB092 in progressive supranuclear palsy: a randomised, placebo-controlled, multiple ascending dose phase $1 \mathrm{~b}$ trial. Lancet Neurol 18:549-558. https://doi.org/10.1016/S1474 $-4422(19) 30139-5$

19. Braak H, Braak E (1996) Development of Alzheimer-related neurofibrillary changes in the neocortex inversely recapitulates cortical myelogenesis. Acta Neuropathol 92:197-201. https://doi. org/10.1007/s004010050508

20. Braak H, Braak E (1991) Neuropathological stageing of Alzheimer-related changes. Acta Neuropathol 82:239-259. https://doi. org/10.1007/bf00308809
21. Braak H, Del Tredici K (2011) Alzheimer's disease: pathogenesis and prevention. Alzheimers Dement 8:227-233. https://doi. org/10.1016/j.jalz.2012.01.011

22. Braak H, Del Tredici K (2013) Evolutional aspects of Alzheimer's disease pathogenesis. J Alzheimers Dis 33(Suppl 1):S155161. https://doi.org/10.3233/JAD-2012-129029

23. Brandt R, Leger J, Lee G (1995) Interaction of tau with the neural plasma membrane mediated by tau's amino-terminal projection domain. J Cell Biol 131:1327-1340. https://doi.org/10.1083/ jcb.131.5.1327

24. Brendel M, Schonecker S, Hoglinger G, Lindner S, Havla J, Blautzik J et al (2017) [(18)F]-THK5351 PET correlates with topology and symptom severity in progressive supranuclear palsy. Front Aging Neurosci 9:440. https://doi.org/10.3389/ fnagi.2017.00440

25. Bright J, Hussain S, Dang V, Wright S, Cooper B, Byun T et al (2015) Human secreted tau increases amyloid-beta production. Neurobiol Aging 36:693-709. https://doi.org/10.1016/j.neuro biolaging.2014.09.007

26. Bruhns P, Iannascoli B, England P, Mancardi DA, Fernandez N, Jorieux S et al (2009) Specificity and affinity of human Fcgamma receptors and their polymorphic variants for human IgG subclasses. Blood 113:3716-3725. https://doi. org/10.1182/blood-2008-09-179754

27. Buee L, Bussiere T, Buee-Scherrer V, Delacourte A, Hof PR (2000) Tau protein isoforms, phosphorylation and role in neurodegenerative disorders. Brain Res Brain Res Rev 33:95-130

28. Buee L, Troquier L, Burnouf S, Belarbi K, Van der Jeugd A, Ahmed T et al (2010) From tau phosphorylation to tau aggregation: what about neuronal death? Biochem Soc Trans 38:967-972. https://doi.org/10.1042/BST0380967

29. Burnouf S, Martire A, Derisbourg M, Laurent C, Belarbi K, Leboucher A et al (2013) NMDA receptor dysfunction contributes to impaired brain-derived neurotrophic factorinduced facilitation of hippocampal synaptic transmission in a Tau transgenic model. Aging Cell 12:11-23. https://doi. org/10.1111/acel.12018

30. Caillierez R, Begard S, Lecolle K, Deramecourt V, Zommer N, Dujardin S et al (2013) Lentiviral delivery of the human wildtype tau protein mediates a slow and progressive neurodegenerative tau pathology in the rat brain. Mol Ther 21:1358-1368. https ://doi.org/10.1038/mt.2013.66

31. Calafate S, Buist A, Miskiewicz K, Vijayan V, Daneels G, de Strooper B et al (2015) Synaptic contacts enhance cell-to-cell tau pathology propagation. Cell Rep 11:1176-1183. https://doi. org/10.1016/j.celrep.2015.04.043

32. Calafate S, Flavin W, Verstreken P, Moechars D (2016) Loss of Bin1 promotes the propagation of tau pathology. Cell Rep 17:931-940. https://doi.org/10.1016/j.celrep.2016.09.063

33. Castillo-Carranza DL, Guerrero-Munoz MJ, Sengupta U, Hernandez C, Barrett AD, Dineley K et al (2015) Tau immunotherapy modulates both pathological tau and upstream amyloid pathology in an Alzheimer's disease mouse model. J Neurosci 35:4857-4868. https://doi.org/10.1523/JNEUR OSCI.4989-14.2015

34. Castillo-Carranza DL, Sengupta U, Guerrero-Munoz MJ, Lasagna-Reeves CA, Gerson JE, Singh G et al (2014) Passive immunization with tau oligomer monoclonal antibody reverses tauopathy phenotypes without affecting hyperphosphorylated neurofibrillary tangles. J Neurosci 34:4260-4272. https://doi. org/10.1523/JNEUROSCI.3192-13.2014

35. Chai X, Wu S, Murray TK, Kinley R, Cella CV, Sims H et al (2011) Passive immunization with anti-Tau antibodies in two transgenic models: reduction of Tau pathology and delay of disease progression. J Biol Chem 286:34457-34467. https://doi. org/10.1074/jbc.M111.229633 
36. Chang E, Kim S, Yin H, Nagaraja HN, Kuret J (2008) Pathogenic missense MAPT mutations differentially modulate tau aggregation propensity at nucleation and extension steps. J Neurochem 107:1113-1123. https://doi.org/10.1111/j.1471-4159.2008.05692 .x

37. Chapel HM, Esiri MM, Wilcock GK (1984) Immunoglobulin and other proteins in the cerebrospinal fluid of patients with Alzheimer's disease. J Clin Pathol 37:697-699. https://doi.org/10.1136/ jcp.37.6.697

38. Chapin SJ, Bulinski JC (1992) Microtubule stabilization by assembly-promoting microtubule-associated proteins: a repeat performance. Cell Motil Cytoskelet 23:236-243. https://doi. org/10.1002/cm.970230403

39. Chauderlier A, Gilles M, Spolcova A, Caillierez R, Chwastyniak M, Kress M et al (2018) Tau/DDX6 interaction increases microRNA activity. Biochim Biophys Acta Gene Regul Mech 1861:762-772. https://doi.org/10.1016/j.bbagrm.2018.06.006

40. Chen Z, Mengel D, Keshavan A, Rissman RA, Billinton A, Perkinton $M$ et al (2018) Learnings about the complexity of extracellular tau aid development of a blood-based screen for Alzheimer's disease. Alzheimers Dement 15:487-496. https:// doi.org/10.1016/j.jalz.2018.09.010

41. Chiu MJ, Fan LY, Chen TF, Chen YF, Chieh JJ, Horng HE (2017) Plasma tau levels in cognitively normal middle-aged and older adults. Front Aging Neurosci 9:51. https://doi.org/10.3389/fnagi .2017.00051

42. Cho H, Choi JY, Hwang MS, Kim YJ, Lee HM, Lee HS et al (2016) In vivo cortical spreading pattern of tau and amyloid in the Alzheimer disease spectrum. Ann Neurol 80:247-258. https ://doi.org/10.1002/ana.24711

43. Cicognola C, Brinkmalm G, Wahlgren J, Portelius E, Gobom J, Cullen NC et al (2019) Novel tau fragments in cerebrospinal fluid: relation to tangle pathology and cognitive decline in Alzheimer's disease. Acta Neuropathol 137:279-296. https://doi. org/10.1007/s00401-018-1948-2

44. Clavaguera F, Akatsu H, Fraser G, Crowther RA, Frank S, Hench J et al (2013) Brain homogenates from human tauopathies induce tau inclusions in mouse brain. Proc Natl Acad Sci USA 110:9535-9540. https://doi.org/10.1073/pnas.1301175110

45. Clavaguera F, Bolmont T, Crowther RA, Abramowski D, Frank S, Probst A et al (2009) Transmission and spreading of tauopathy in transgenic mouse brain. Nat Cell Biol 11:909-913. https://doi. org/10.1038/ncb1901

46. Clavaguera F, Hench J, Lavenir I, Schweighauser G, Frank S, Goedert $\mathrm{M}$ et al (2014) Peripheral administration of tau aggregates triggers intracerebral tauopathy in transgenic mice. Acta Neuropathol 127:299-301. https://doi.org/10.1007/s0040 1-013-1231-5

47. Collin L, Bohrmann B, Gopfert U, Oroszlan-Szovik K, Ozmen L, Gruninger F (2014) Neuronal uptake of tau/pS422 antibody and reduced progression of tau pathology in a mouse model of Alzheimer's disease. Brain 137:2834-2846. https://doi.org/10.1093/ brain/awu213

48. Cope TE, Rittman T, Borchert RJ, Jones PS, Vatansever D, Allinson K et al (2018) Tau burden and the functional connectome in Alzheimer's disease and progressive supranuclear palsy. Brain 141:550-567. https://doi.org/10.1093/brain/awx347

49. Courade JP, Angers R, Mairet-Coello G, Pacico N, Tyson K, Lightwood D et al (2018) Epitope determines efficacy of therapeutic anti-Tau antibodies in a functional assay with human Alzheimer Tau. Acta Neuropathol 136:729-745. https://doi. org/10.1007/s00401-018-1911-2

50. d'Abramo C, Acker CM, Jimenez HT, Davies P (2013) Tau passive immunotherapy in mutant P301L mice: antibody affinity versus specificity. PLoS ONE 8:e62402.https://doi.org/10.1371/ journal.pone.0062402
51. Dage JL, Wennberg AMV, Airey DC, Hagen CE, Knopman DS, Machulda MM et al (2016) Levels of tau protein in plasma are associated with neurodegeneration and cognitive function in a population-based elderly cohort. Alzheimers Dement 12:12261234. https://doi.org/10.1016/j.jalz.2016.06.001

52. Dai CL, Chen X, Kazim SF, Liu F, Gong CX, Grundke-Iqbal I (2015) Passive immunization targeting the $\mathrm{N}$-terminal projection domain of tau decreases tau pathology and improves cognition in a transgenic mouse model of Alzheimer disease and tauopathies. J Neural Transm (Vienna) 122:607-617. https://doi.org/10.1007/ s00702-014-1315-y

53. Dai CL, Chen X, Kazim SF, Liu F, Gong CX, Grundke-Iqbal I et al (2015) Passive immunization targeting the N-terminal projection domain of tau decreases tau pathology and improves cognition in a transgenic mouse model of Alzheimer disease and tauopathies. J Neural Transm (Vienna) 122:607-617. https://doi. org/10.1007/s00702-014-1315-y

54. Dai CL, Tung YC, Liu F, Gong CX, Iqbal K (2017) Tau passive immunization inhibits not only tau but also Abeta pathology. Alzheimers Res Ther 9:1. https://doi.org/10.1186/s1319 5-016-0227-5

55. de Calignon A, Polydoro M, Suarez-Calvet M, William C, Adamowicz DH, Kopeikina KJ et al (2012) Propagation of tau pathology in a model of early Alzheimer's disease. Neuron 73:685-697. https://doi.org/10.1016/j.neuron.2011.11.033

56. Deters KD, Risacher SL, Kim S, Nho K, West JD, Blennow K et al (2017) Plasma tau association with brain atrophy in mild cognitive impairment and Alzheimer's disease. J Alzheimers Dis 58:1245-1254. https://doi.org/10.3233/JAD-161114

57. DeVos SL, Corjuc BT, Oakley DH, Nobuhara CK, Bannon RN, Chase A et al (2018) Synaptic tau seeding precedes tau pathology in human Alzheimer's disease brain. Front Neurosci 12:267. https://doi.org/10.3389/fnins.2018.00267

58. Dinkel PD, Holden MR, Matin N, Margittai M (2015) RNA binds to tau fibrils and sustains template-assisted growth. Biochemistry 54:4731-4740. https://doi.org/10.1021/acs.biochem.5b00453

59. Dujardin S, Begard S, Caillierez R, Lachaud C, Carrier S, Lieger $S$ et al (2018) Different tau species lead to heterogeneous tau pathology propagation and misfolding. Acta Neuropathol Commun 6:132. https://doi.org/10.1186/s40478-018-0637-7

60. Dujardin S, Begard S, Caillierez R, Lachaud C, Delattre L, Carrier $S$ et al (2014) Ectosomes: a new mechanism for non-exosomal secretion of tau protein. PLoS ONE 9:e100760. https://doi. org/10.1371/journal.pone.0100760

61. Dujardin S, Colin M, Buee L (2015) Invited review: animal models of tauopathies and their implications for research/translation into the clinic. Neuropathol Appl Neurobiol 41:59-80. https:// doi.org/10.1111/nan.12200

62. Dujardin S, Commins C, Kamath TV, Corjuc DL, Corjuc BT, Gonzalez JA et al (2018) Heterogeneity and predictability of tau seeding in the human brain, relevance for heterogeneity in clinical and neuropathological phenotypes and immunotherapy for Alzheimer's disease. Neuroscience Meeting Planner San Diego, CA: Society for Neuroscience Program No. 627.06

63. Dujardin S, Lecolle K, Caillierez R, Begard S, Zommer N, Lachaud C et al (2014) Neuron-to-neuron wild-type Tau protein transfer through a trans-synaptic mechanism: relevance to sporadic tauopathies. Acta Neuropathol Commun 2:14. https://doi. org/10.1186/2051-5960-2-14

64. Duyckaerts C, Uchihara T, Seilhean D, He Y, Hauw JJ (1997) Dissociation of Alzheimer type pathology in a disconnected piece of cortex. Acta Neuropathol 93:501-507. https://doi. org/10.1007/s004010050645

65. Eisele YS, Duyckaerts C (2016) Propagation of Ass pathology: hypotheses, discoveries, and yet unresolved questions 
from experimental and human brain studies. Acta Neuropathol 131:5-25. https://doi.org/10.1007/s00401-015-1516-y

66. Evans LD, Wassmer T, Fraser G, Smith J, Perkinton M, Billinton A et al (2018) Extracellular monomeric and aggregated tau efficiently enter human neurons through overlapping but distinct pathways. Cell Rep 22:3612-3624. https://doi.org/10.1016/j.celre p.2018.03.021

67. Falcon B, Zhang W, Schweighauser M, Murzin AG, Vidal R, Garringer HJ et al (2018) Tau filaments from multiple cases of sporadic and inherited Alzheimer's disease adopt a common fold. Acta Neuropathol 136:699-708. https://doi.org/10.1007/s0040 1-018-1914-Z

68. Falcon B, Zivanov J, Zhang W, Murzin AG, Garringer HJ, Vidal R et al (2019) Novel tau filament fold in chronic traumatic encephalopathy encloses hydrophobic molecules. Nature 568:420-423. https://doi.org/10.1038/s41586-019-1026-5

69. Fernandez-Vizarra P, Lopez-Franco O, Mallavia B, HigueraMatas A, Lopez-Parra V, Ortiz-Munoz G et al (2012) Immunoglobulin G Fc receptor deficiency prevents Alzheimer-like pathology and cognitive impairment in mice. Brain 135:28262837. https://doi.org/10.1093/brain/aws195

70. Fiandaca MS, Kapogiannis D, Mapstone M, Boxer A, Eitan E, Schwartz JB et al (2015) Identification of preclinical Alzheimer's disease by a profile of pathogenic proteins in neurally derived blood exosomes: a case-control study. Alzheimers Dement 11(600-607):e601. https://doi.org/10.1016/j.jalz.2014.06.008

71. Fitzpatrick AWP, Falcon B, He S, Murzin AG, Murshudov G, Garringer HJ et al (2017) Cryo-EM structures of tau filaments from Alzheimer's disease. Nature 547:185-190. https://doi. org/10.1038/nature23002

72. Foiani MS, Woollacott IO, Heller C, Bocchetta M, Heslegrave A, Dick KM et al (2018) Plasma tau is increased in frontotemporal dementia. J Neurol Neurosurg Psychiatry 89:804-807. https:// doi.org/10.1136/jnnp-2017-317260

73. Forrest SL, Kril JJ, Halliday GM (2019) Cellular and regional vulnerability in frontotemporal tauopathies. Acta Neuropathol. https://doi.org/10.1007/s00401-019-02035-7

74. Forrest SL, Kril JJ, Halliday GM (2018) Reply: Will FTLD-tau work for all when FTDP-17 retires? Brain 141:e63. https://doi. org/10.1093/brain/awy179

75. Frost B, Jacks RL, Diamond MI (2009) Propagation of tau misfolding from the outside to the inside of a cell. J Biol Chem 284:12845-12852. https://doi.org/10.1074/jbc.M808759200

76. Funk KE, Mirbaha H, Jiang H, Holtzman DM, Diamond MI (2015) Distinct therapeutic mechanisms of tau antibodies: promoting microglial clearance versus blocking neuronal uptake. J Biol Chem 290:21652-21662. https://doi.org/10.1074/jbc. M115.657924

77. Gallo P, Bracco F, Morara S, Battistin L, Tavolato B (1985) The cerebrospinal fluid transferrin/tau proteins. A study by twodimensional polyacrylamide gel electrophoresis (2D) and agarose isoelectrofocusing (IEF) followed by double-antibody peroxidase labeling and avidin-biotin amplification. J Neurol Sci 70:81-92. https://doi.org/10.1016/0022-510x(85)90190-x

78. Ginsberg SD, Alldred MJ, Counts SE, Cataldo AM, Neve RL, Jiang Y et al (2010) Microarray analysis of hippocampal CA1 neurons implicates early endosomal dysfunction during Alzheimer's disease progression. Biol Psychiatry 68:885-893. https:// doi.org/10.1016/j.biopsych.2010.05.030

79. Ginsberg SD, Mufson EJ, Alldred MJ, Counts SE, Wuu J, Nixon RA et al (2011) Upregulation of select rab GTPases in cholinergic basal forebrain neurons in mild cognitive impairment and Alzheimer's disease. J Chem Neuroanat 42:102-110. https://doi. org/10.1016/j.jchemneu.2011.05.012

80. Ginsberg SD, Mufson EJ, Counts SE, Wuu J, Alldred MJ, Nixon RA et al (2010) Regional selectivity of rab5 and rab7 protein upregulation in mild cognitive impairment and Alzheimer's disease. J Alzheimers Dis 22:631-639. https://doi.org/10.3233/ JAD-2010-101080

81. Goedert M, Spillantini MG, Jakes R, Rutherford D, Crowther RA (1989) Multiple isoforms of human microtubule-associated protein tau: sequences and localization in neurofibrillary tangles of Alzheimer's disease. Neuron 3:519-526

82. Goedert M, Spillantini MG, Potier MC, Ulrich J, Crowther RA (1989) Cloning and sequencing of the cDNA encoding an isoform of microtubule-associated protein tau containing four tandem repeats: differential expression of tau protein mRNAs in human brain. EMBO J 8:393-399

83. Gomez-Ramos A, Diaz-Hernandez M, Rubio A, Miras-Portugal MT, Avila J (2008) Extracellular tau promotes intracellular calcium increase through M1 and M3 muscarinic receptors in neuronal cells. Mol Cell Neurosci 37:673-681. https://doi. org/10.1016/j.mcn.2007.12.010

84. Graham D, Weiping C, Julie C, Anne C, Paul W, Qin W et al (2017) In vivo demonstration than pan tau antibody, BIIB076, reduces free tau in cynomolgus monkey cerebrospinal fluid. In: AD/PD 2017, the 13th international conference on Alzheimer's \& Parkinson's diseases

85. Guix FX, Corbett GT, Cha DJ, Mustapic M, Liu W, Mengel D et al (2018) Detection of aggregation-competent tau in neuron-derived extracellular vesicles. Int J Mol Sci. https://doi. org/10.3390/ijms 19030663

86. Guo JL, Lee VM (2011) Seeding of normal Tau by pathological Tau conformers drives pathogenesis of Alzheimer-like tangles. J Biol Chem 286:15317-15331. https://doi.org/10.1074/jbc. M110.209296

87. Guo T, Noble W, Hanger DP (2017) Roles of tau protein in health and disease. Acta Neuropathol 133:665-704. https://doi. org/10.1007/s00401-017-1707-9

88. Hanisch K, Soininen H, Alafuzoff I, Hoffmann R (2010) Analysis of human tau in cerebrospinal fluid. J Proteome Res 9:14761482. https://doi.org/10.1021/pr901002t

89. Hillered L, Persson L, Nilsson P, Ronne-Engstrom E, Enblad P (2006) Continuous monitoring of cerebral metabolism in traumatic brain injury: a focus on cerebral microdialysis. Curr Opin Crit Care 12:112-118. https://doi.org/10.1097/01.ccx.00002 16576.11439.df

90. Himmler A, Drechsel D, Kirschner MW, Martin DW (1989) Tau consists of a set of proteins with repeated C-terminal microtubule-binding domains and variable $\mathrm{N}$-terminal domains. Mol Cell Biol 9:1381-1388. https://doi.org/10.1128/mcb.9.4.1381

91. Hoenig MC, Bischof GN, Seemiller J, Hammes J, Kukolja J, Onur OA et al (2018) Networks of tau distribution in Alzheimer's disease. Brain 141:568-581. https://doi.org/10.1093/brain/awx35

92. Hof PR, Morrison JH (1996) Hippocampal and neocortical involvement in normal brain aging and dementia: morphological and neurochemical profile of the vulnerable circuits. J Am Geriatr Soc 44:857-864. https://doi.org/10.1111/j.1532-5415.1996. tb03748.x

93. Holmes BB, Devos SL, Kfoury N, Li M, Jacks R, Yanamandra $\mathrm{K}$ et al (2013) Heparan sulfate proteoglycans mediate internalization and propagation of specific proteopathic seeds. Proc Natl Acad Sci USA 110:E3138-3147. https://doi.org/10.1073/ pnas. 1301440110

94. Holmes BB, Furman JL, Mahan TE, Yamasaki TR, Mirbaha H, Eades WC et al (2014) Proteopathic tau seeding predicts tauopathy in vivo. Proc Natl Acad Sci USA 111:E4376-4385. https:// doi.org/10.1073/pnas.1411649111

95. Iliff JJ, Chen MJ, Plog BA, Zeppenfeld DM, Soltero M, Yang L et al (2014) Impairment of glymphatic pathway function promotes tau pathology after traumatic brain injury. $\mathrm{J}$ 
Neurosci 34:16180-16193. https://doi.org/10.1523/JNEUR OSCI.3020-14.2014

96. Irwin DJ, Brettschneider J, McMillan CT, Cooper F, Olm C, Arnold SE et al (2016) Deep clinical and neuropathological phenotyping of Pick disease. Ann Neurol 79:272-287. https://doi. org/10.1002/ana.24559

97. Irwin DJ, Lee VM, Trojanowski JQ (2013) Parkinson's disease dementia: convergence of alpha-synuclein, tau and amyloidbeta pathologies. Nat Rev Neurosci 14:626-636. https://doi. org/10.1038/nrn3549

98. Ising $\mathrm{C}$, Gallardo $\mathrm{G}$, Leyns $\mathrm{CEG}$, Wong $\mathrm{CH}$, Jiang H, Stewart $\mathrm{F}$ et al (2017) AAV-mediated expression of anti-tau scFvs decreases tau accumulation in a mouse model of tauopathy. J Exp Med 214:1227-1238. https://doi.org/10.1084/jem.20162125

99. Ittner LM, Ke YD, Delerue F, Bi M, Gladbach A, van Eersel J et al (2010) Dendritic function of tau mediates amyloid-beta toxicity in Alzheimer's disease mouse models. Cell 142:387-397. https://doi.org/10.1016/j.cell.2010.06.036

100. Jadhav S, Avila J, Scholl M, Kovacs GG, Kovari E, Skrabana $\mathrm{R}$ et al (2019) A walk through tau therapeutic strategies. Acta Neuropathol Commun 7:22. https://doi.org/10.1186/s4047 8-019-0664-Z

101. Jicha GA, Bowser R, Kazam IG, Davies P (1997) Alz-50 and MC-1, a new monoclonal antibody raised to paired helical filaments, recognize conformational epitopes on recombinant tau. $\mathbf{J}$ Neurosci Res 48:128-132. https://doi.org/10.1002/(SICI)10974547(19970415)48:2\%3c128:AID-JNR5\%3e3.0.CO;2-E

102. Jucker M, Walker LC (2013) Self-propagation of pathogenic protein aggregates in neurodegenerative diseases. Nature 501:45-51. https://doi.org/10.1038/nature12481

103. Katsinelos T, Zeitler M, Dimou E, Karakatsani A, Muller HM, Nachman E et al (2018) Unconventional secretion mediates the trans-cellular spreading of tau. Cell Rep 23:2039-2055. https:// doi.org/10.1016/j.celrep.2018.04.056

104. Kaufman SK, Diamond MI (2013) Prion-like propagation of protein aggregation and related therapeutic strategies. Neurotherapeutics 10:371-382. https://doi.org/10.1007/s13311-013-0196-3

105. Kaufman SK, Sanders DW, Thomas TL, Ruchinskas AJ, VaquerAlicea J, Sharma AM et al (2016) Tau prion strains dictate patterns of cell pathology, progression rate, and regional vulnerability in vivo. Neuron 92:796-812. https://doi.org/10.1016/j.neuro n.2016.09.055

106. Kfoury N, Holmes BB, Jiang H, Holtzman DM, Diamond MI (2012) Trans-cellular propagation of tau aggregation by fibrillar species. J Biol Chem 287:19440-19451. https://doi.org/10.1074/ jbc.M112.346072

107. Kolb HC, Triana-Baltzer G, Slemmon JR, Janssen Pharmaceutical NV (2019) Assays to detect neurodegeneration. United States Patent Application 20190271710A1

108. Kovacs GG (2015) Invited review: neuropathology of tauopathies: principles and practice. Neuropathol Appl Neurobiol 41:3-23. https://doi.org/10.1111/nan.12208

109. Kovacs GG, Xie SX, Robinson JL, Lee EB, Smith DH, Schuck $\mathrm{T}$ (2018) Sequential stages and distribution patterns of agingrelated tau astrogliopathy (ARTAG) in the human brain. Acta Neuropathol Commun 6:50. https://doi.org/10.1186/s4047 8-018-0552-y

110. Lebouvier T, Pasquier F, Buee L (2017) Update on tauopathies. Curr Opin Neurol 30:589-598. https://doi.org/10.1097/ WCO.0000000000000502

111. Lee SH, Le Pichon CE, Adolfsson O, Gafner V, Pihlgren M, Lin $\mathrm{H}$ et al (2016) Antibody-mediated targeting of tau in vivo does not require effector function and microglial engagement. Cell Rep 16:1690-1700. https://doi.org/10.1016/j.celrep.2016.06.099

112. Leuzy A, Chiotis K, Lemoine L, Gillberg PG, Almkvist O, Rodriguez-Vieitez E et al (2019) Tau PET imaging in neurodegenerative tauopathies-still a challenge. Mol Psychiatry 24:1112-1134. https://doi.org/10.1038/s41380-018-0342-8

113. Lewis J, Dickson DW (2016) Propagation of tau pathology: hypotheses, discoveries, and yet unresolved questions from experimental and human brain studies. Acta Neuropathol 131:27-48. https://doi.org/10.1007/s00401-015-1507-z

114. Lewis SA, Wang DH, Cowan NJ (1988) Microtubule-associated protein MAP2 shares a microtubule binding motif with tau protein. Science 242:936-939. https://doi.org/10.1126/scien ce. 3142041

115. Lin CH, Yang SY, Horng HE, Yang CC, Chieh JJ, Chen HH et al (2018) Plasma biomarkers differentiate Parkinson's disease from atypical Parkinsonism syndromes. Front Aging Neurosci 10:123. https://doi.org/10.3389/fnagi.2018.00123

116. Liu L, Drouet V, Wu JW, Witter MP, Small SA, Clelland C et al (2012) Trans-synaptic spread of tau pathology in vivo. PLoS ONE 7:e31302. https://doi.org/10.1371/journal.pone.00313 02PONE-D-11-23353

117. Loomis PA, Howard TH, Castleberry RP, Binder LI (1990) Identification of nuclear tau isoforms in human neuroblastoma cells. Proc Natl Acad Sci USA 87:8422-8426. https://doi.org/10.1073/ pnas.87.21.8422

118. Lue LF, Sabbagh MN, Chiu MJ, Jing N, Snyder NL, Schmitz C et al (2017) Plasma levels of Abeta42 and tau identified probable Alzheimer's dementia: findings in two cohorts. Front Aging Neurosci 9:226. https://doi.org/10.3389/fnagi.2017.00226

119. Man SM, Kanneganti TD (2015) Regulation of inflammasome activation. Immunol Rev 265:6-21. https://doi.org/10.1111/ imr.12296

120. Mansuroglu Z, Benhelli-Mokrani H, Marcato V, Sultan A, Violet M, Chauderlier A et al (2016) Loss of Tau protein affects the structure, transcription and repair of neuronal pericentromeric heterochromatin. Sci Rep 6:33047. https://doi.org/10.1038/srep3 3047

121. Marciniak E, Leboucher A, Caron E, Ahmed T, Tailleux A, Dumont J et al (2017) Tau deletion promotes brain insulin resistance. J Exp Med 214:2257-2269. https://doi.org/10.1084/ jem. 20161731

122. Martini-Stoica H, Cole AL, Swartzlander DB, Chen F, Wan YW, Bajaj L et al (2018) TFEB enhances astroglial uptake of extracellular tau species and reduces tau spreading. J Exp Med 215:2355-2377. https://doi.org/10.1084/jem.20172158

123. Mattsson N, Zetterberg H, Hansson O, Andreasen N, Parnetti L, Jonsson $\mathrm{M}$ et al (2009) CSF biomarkers and incipient Alzheimer disease in patients with mild cognitive impairment. JAMA 302:385-393. https://doi.org/10.1001/jama.2009.1064

124. Mattsson N, Zetterberg H, Janelidze S, Insel PS, Andreasson U, Stomrud E et al (2016) Plasma tau in Alzheimer disease. Neurology 87:1827-1835. https://doi.org/10.1212/WNL.0000000000 003246

125. Merezhko M, Brunello CA, Yan X, Vihinen H, Jokitalo E, Uronen RL et al (2018) Secretion of tau via an unconventional non-vesicular mechanism. Cell Rep 25(2027-2035):e2024. https ://doi.org/10.1016/j.celrep.2018.10.078

126. Mielke MM, Hagen CE, Wennberg AMV, Airey DC, Savica R, Knopman DS et al (2017) Association of plasma total tau level with cognitive decline and risk of mild cognitive impairment or dementia in the Mayo Clinic study on aging. JAMA Neurol 74:1073-1080. https://doi.org/10.1001/jamaneurol.2017.1359

127. Mielke MM, Hagen CE, Xu J, Chai X, Vemuri P, Lowe VJ et al (2018) Plasma phospho-tau181 increases with Alzheimer's disease clinical severity and is associated with tau- and amyloidpositron emission tomography. Alzheimers Dement 14:989-997. https://doi.org/10.1016/j.jalz.2018.02.013 
128. Mohamed NV, Desjardins A, Leclerc N (2017) Tau secretion is correlated to an increase of Golgi dynamics. PLoS ONE 12:e0178288. https://doi.org/10.1371/journal.pone.0178288

129. Mondragon-Rodriguez S, Trillaud-Doppia E, Dudilot A, Bourgeois C, Lauzon M, Leclerc N et al (2012) Interaction of endogenous tau protein with synaptic proteins is regulated by $\mathrm{N}$-methylD-aspartate receptor-dependent tau phosphorylation. J Biol Chem 287:32040-32053. https://doi.org/10.1074/jbc.M112.401240

130. Mudher A, Colin M, Dujardin S, Medina M, Dewachter I, Alavi Naini SM et al (2017) What is the evidence that tau pathology spreads through prion-like propagation? Acta Neuropathol Commun 5:99. https://doi.org/10.1186/s40478-017-0488-7

131. Muller S, Preische O, Gopfert JC, Yanez VAC, Joos TO, Boecker $\mathrm{H}$ et al (2017) Tau plasma levels in subjective cognitive decline: results from the DELCODE study. Sci Rep 7:9529. https://doi. org/10.1038/s41598-017-08779-0

132. Narasimhan S, Guo JL, Changolkar L, Stieber A, McBride JD, Silva LV et al (2017) Pathological tau strains from human brains recapitulate the diversity of tauopathies in nontransgenic mouse brain. J Neurosci 37:11406-11423. https://doi.org/10.1523/ JNEUROSCI.1230-17.2017

133. Noble W, Hanger DP, Miller CC, Lovestone S (2013) The importance of tau phosphorylation for neurodegenerative diseases. Front Neurol 4:83. https://doi.org/10.3389/fneur.2013.00083

134. Nobuhara CK, DeVos SL, Commins C, Wegmann S, Moore BD, Roe AD et al (2017) Tau antibody targeting pathological species blocks neuronal uptake and interneuron propagation of tau in vitro. Am J Pathol 187:1399-1412. https://doi.org/10.1016/j. ajpath.2017.01.022

135. Nonaka T, Watanabe ST, Iwatsubo T, Hasegawa M (2010) Seeded aggregation and toxicity of $\{$ alpha $\}$-synuclein and tau: cellular models of neurodegenerative diseases. J Biol Chem 285:34885-34898. https://doi.org/10.1074/jbc.M110.148460

136. Okun E, Mattson MP, Arumugam TV (2010) Involvement of Fc receptors in disorders of the central nervous system. Neuromol Med 12:164-178. https://doi.org/10.1007/s12017-009-8099-5

137. Pandya S, Mezias C, Raj A (2017) Predictive model of spread of progressive supranuclear palsy using directional network diffusion. Front Neurol 8:692. https://doi.org/10.3389/fneur 2017.00692

138. Pase MP, Beiser AS, Himali JJ, Satizabal CL, Aparicio HJ, DeCarli C et al (2019) Assessment of plasma total tau level as a predictive biomarker for dementia and related endophenotypes. JAMA Neurol 76:598-606. https://doi.org/10.1001/jamaneurol .2018 .4666

139. Patel TK, Habimana-Griffin L, Gao X, Xu B, Achilefu S, Alitalo $\mathrm{K}$ et al (2019) Dural lymphatics regulate clearance of extracellular tau from the CNS. Mol Neurodegener 14:11. https://doi. org/10.1186/s13024-019-0312-x

140. Perez M, Avila J, Hernandez F (2019) Propagation of tau via extracellular vesicles. Front Neurosci 13:698. https://doi. org/10.3389/fnins.2019.00698

141. Perez M, Medina M, Hernandez F, Avila J (2018) Secretion of full-length Tau or Tau fragments in cell culture models. Propagation of Tau in vivo and in vitro. Biomol Concepts 9:1-11. https ://doi.org/10.1515/bmc-2018-0001

142. Pernegre C, Duquette A, Leclerc N (2019) Tau secretion: good and bad for neurons. Front Neurosci 13:649. https://doi. org/10.3389/fnins.2019.00649

143. Polanco JC, Li C, Durisic N, Sullivan R, Gotz J (2018) Exosomes taken up by neurons hijack the endosomal pathway to spread to interconnected neurons. Acta Neuropathol Commun 6:10. https ://doi.org/10.1186/s40478-018-0514-4

144. Qi H, Cantrelle FX, Benhelli-Mokrani H, Smet-Nocca C, Buee L, Lippens $\mathrm{G}$ et al (2015) Nuclear magnetic resonance spectroscopy characterization of interaction of Tau with DNA and its regulation by phosphorylation. Biochemistry $54: 1525-1533$. https://doi.org/10.1021/bi5014613

145. Rapoport SI (1989) Hypothesis: Alzheimer's disease is a phylogenetic disease. Med Hypotheses 29:147-150. https://doi. org/10.1016/0306-9877(89)90185-0

146. Rauch JN, Chen JJ, Sorum AW, Miller GM, Sharf T, See SK et al (2018) Tau internalization is regulated by 6-O sulfation on heparan sulfate proteoglycans (HSPGs). Sci Rep 8:6382. https:// doi.org/10.1038/s41598-018-24904-z

147. Reiber H (2001) Dynamics of brain-derived proteins in cerebrospinal fluid. Clin Chim Acta 310:173-186. https://doi. org/10.1016/s0009-8981(01)00573-3

148. Reilly P, Winston CN, Baron KR, Trejo M, Rockenstein EM, Akers JC et al (2017) Novel human neuronal tau model exhibiting neurofibrillary tangles and transcellular propagation. Neurobiol Dis 106:222-234. https://doi.org/10.1016/j.nbd.2017.06.005

149. Rodriguez L, Mohamed NV, Desjardins A, Lippe R, Fon EA, Leclerc N (2017) Rab7A regulates tau secretion. J Neurochem 141:592-605. https://doi.org/10.1111/jnc. 13994

150. Rogers MB (2018) To block tau's proteopathic spread, antibody must attack its mid-region. AlzForum https://www.alzforum.org/ news/conference-coverage/block-taus-proteopathic-spread-antib ody-must-attack-its-mid-region. Accessed 28 Oct 2019

151. Saito T, Mihira N, Matsuba Y, Sasaguri H, Hashimoto S, Narasimhan S et al (2019) Humanization of the entire murine Mapt gene provides a murine model of pathological human tau propagation. J Biol Chem 294:12754-12765. https://doi.org/10.1074/ jbc.RA119.009487

152. Saito Y, Ruberu NN, Sawabe M, Arai T, Tanaka N, Kakuta Y et al (2004) Staging of argyrophilic grains: an age-associated tauopathy. J Neuropathol Exp Neurol 63:911-918. https://doi. org/10.1093/jnen/63.9.911

153. Saman S, Kim W, Raya M, Visnick Y, Miro S, Jackson B et al (2012) Exosome-associated tau is secreted in tauopathy models and is selectively phosphorylated in cerebrospinal fluid in early Alzheimer disease. J Biol Chem 287:3842-3849. https://doi. org/10.1074/jbc.M111.277061

154. Sanders DW, Kaufman SK, DeVos SL, Sharma AM, Mirbaha H, $\mathrm{Li} A$ et al (2014) Distinct tau prion strains propagate in cells and mice and define different tauopathies. Neuron 82:1271-1288. https://doi.org/10.1016/j.neuron.2014.04.047

155. Sankaranarayanan S, Barten DM, Vana L, Devidze N, Yang L, Cadelina $G$ et al (2015) Passive immunization with phospho-tau antibodies reduces tau pathology and functional deficits in two distinct mouse tauopathy models. PLoS ONE 10:e0125614. https ://doi.org/10.1371/journal.pone.0125614

156. Santa-Maria I, Varghese M, Ksiezak-Reding H, Dzhun A, Wang J, Pasinetti GM (2012) Paired helical filaments from Alzheimer disease brain induce intracellular accumulation of tau protein in aggresomes. J Biol Chem 287:20522-20533. https://doi. org/10.1074/jbc.M111.323279

157. Santos CR, Duarte AC, Quintela T, Tomas J, Albuquerque T, Marques F et al (2017) The choroid plexus as a sex hormone target: Functional implications. Front Neuroendocrinol 44:103-121. https://doi.org/10.1016/j.yfrne.2016.12.002

158. Sato C, Barthelemy NR, Mawuenyega KG, Patterson BW, Gordon BA, Jockel-Balsarotti J et al (2018) Tau kinetics in neurons and the human central nervous system. Neuron 97(12841298):e1287. https://doi.org/10.1016/j.neuron.2018.02.015

159. Sayas CL, Medina M, Cuadros R, Olla I, Garcia E, Perez M (2019) Role of tau N-terminal motif in the secretion of human tau by end binding proteins. PLoS ONE 14:e0210864. https:// doi.org/10.1371/journal.pone.0210864

160. Sergeant N, Bretteville A, Hamdane M, Caillet-Boudin ML, Grognet P, Bombois S et al (2008) Biochemistry of Tau in 
Alzheimer's disease and related neurological disorders. Expert Rev Proteom 5:207-224. https://doi.org/10.1586/14789 450.5.2.207

161. Shrivastava AN, Redeker V, Pieri L, Bousset L, Renner M, Madiona $\mathrm{K}$ et al (2019) Clustering of Tau fibrils impairs the synaptic composition of alpha3-Na(+)/K(+)-ATPase and AMPA receptors. EMBO J. https://doi.org/10.15252/embj.201899871

162. Sjogren M, Davidsson P, Gottfries J, Vanderstichele H, Edman A, Vanmechelen E et al (2001) The cerebrospinal fluid levels of tau, growth-associated protein-43 and soluble amyloid precursor protein correlate in Alzheimer's disease, reflecting a common pathophysiological process. Dement Geriatr Cogn Disord 12:257-264. https://doi.org/10.1159/000051268

163. Skachokova Z, Martinisi A, Flach M, Sprenger F, Naegelin Y, Steiner-Monard V (2019) Cerebrospinal fluid from Alzheimer's disease patients promotes tau aggregation in transgenic mice. Acta Neuropathol Commun 7:72. https://doi.org/10.1186/ s40478-019-0725-3

164. Sotiropoulos I, Galas MC, Silva JM, Skoulakis E, Wegmann S, Maina MB et al (2017) Atypical, non-standard functions of the microtubule associated Tau protein. Acta Neuropathol Commun 5:91. https://doi.org/10.1186/s40478-017-0489-6

165. Spillantini MG, Goedert M (2013) Tau pathology and neurodegeneration. Lancet Neurol 12:609-622. https://doi. org/10.1016/S1474-4422(13)70090-5

166. Steringer JP, Nickel W (2018) A direct gateway into the extracellular space: unconventional secretion of FGF2 through self-sustained plasma membrane pores. Semin Cell Dev Biol 83:3-7. https://doi.org/10.1016/j.semcdb.2018.02.010

167. Stieber A, Mourelatos Z, Gonatas NK (1996) In Alzheimer's disease the Golgi apparatus of a population of neurons without neurofibrillary tangles is fragmented and atrophic. Am J Pathol 148:415-426

168. Stopschinski BE, Holmes BB, Miller GM, Manon VA, VaquerAlicea J, Prueitt WL et al (2018) Specific glycosaminoglycan chain length and sulfation patterns are required for cell uptake of tau versus alpha-synuclein and beta-amyloid aggregates. J Biol Chem 293:10826-10840. https://doi.org/10.1074/jbc. RA117.000378

169. Sultan A, Nesslany F, Violet M, Begard S, Loyens A, Talahari $S$ et al (2011) Nuclear tau, a key player in neuronal DNA protection. J Biol Chem 286:4566-4575. https://doi.org/10.1074/ jbc.M110.199976

170. Takahashi M, Miyata H, Kametani F, Nonaka T, Akiyama H, Hisanaga $S$ et al (2015) Extracellular association of APP and tau fibrils induces intracellular aggregate formation of tau. Acta Neuropathol 129:895-907. https://doi.org/10.1007/s0040 1-015-1415-2

171. Takeda S, Commins C, DeVos SL, Nobuhara CK, Wegmann S, Roe AD et al (2016) Seed-competent high-molecular-weight tau species accumulates in the cerebrospinal fluid of Alzheimer's disease mouse model and human patients. Ann Neurol 80:355-367. https://doi.org/10.1002/ana.24716

172. Takeda S, Wegmann S, Cho H, DeVos SL, Commins C, Roe AD et al (2015) Neuronal uptake and propagation of a rare phosphorylated high-molecular-weight tau derived from Alzheimer's disease brain. Nat Commun 6:8490. https://doi. org/10.1038/ncomms 9490

173. Tardivel M, Begard S, Bousset L, Dujardin S, Coens A, Melki $\mathrm{R}$ et al (2016) Tunneling nanotube (TNT)-mediated neuron-to neuron transfer of pathological Tau protein assemblies. Acta Neuropathol Commun 4:117. https://doi.org/10.1186/s4047 8-016-0386-4

174. Tatebe H, Kasai T, Ohmichi T, Kishi Y, Kakeya T, Waragai M et al (2017) Quantification of plasma phosphorylated tau to use as a biomarker for brain Alzheimer pathology: pilot case-control studies including patients with Alzheimer's disease and down syndrome. Mol Neurodegener 12:63. https:// doi.org/10.1186/s13024-017-0206-8

175. Telling GC, Parchi P, DeArmond SJ, Cortelli P, Montagna $\mathrm{P}$, Gabizon R et al (1996) Evidence for the conformation of the pathologic isoform of the prion protein enciphering and propagating prion diversity. Science 274:2079-2082. https:// doi.org/10.1126/science.274.5295.2079

176. Troquier L, Caillierez R, Burnouf S, Fernandez-Gomez FJ, Grosjean ME, Zommer N et al (2012) Targeting phosphoSer422 by active Tau immunotherapy in the THYTau 22 mouse model: a suitable therapeutic approach. Curr Alzheimer Res 9:397-405

177. Uchihara T, Giasson BI (2016) Propagation of alpha-synuclein pathology: hypotheses, discoveries, and yet unresolved questions from experimental and human brain studies. Acta Neuropathol 131:49-73. https://doi.org/10.1007/s00401-015-1485-1

178. Umeda T, Eguchi H, Kunori Y, Matsumoto Y, Taniguchi T, Mori $\mathrm{H}$ et al (2015) Passive immunotherapy of tauopathy targeting pSer413-tau: a pilot study in mice. Ann Clin Transl Neurol 2:241-255. https://doi.org/10.1002/acn3.171

179. Vandermeeren M, Borgers M, Van Kolen K, Theunis C, Vasconcelos B, Bottelbergs A et al (2018) Anti-tau monoclonal antibodies derived from soluble and filamentous tau show diverse functional properties in vitro and in vivo. J Alzheimers Dis 65:265-281. https://doi.org/10.3233/JAD-180404

180. Vandermeeren M, Mercken M, Vanmechelen E, Six J, van de Voorde A, Martin JJ et al (1993) Detection of tau proteins in normal and Alzheimer's disease cerebrospinal fluid with a sensitive sandwich enzyme-linked immunosorbent assay. J Neurochem 61:1828-1834. https://doi.org/10.1111/j.1471-4159.1993.tb098 23.x

181. Verny M, Duyckaerts C, Agid Y, Hauw JJ (1996) The significance of cortical pathology in progressive supranuclear palsy. Clinico-pathological data in 10 cases. Brain 119(Pt 4):11231136. https://doi.org/10.1093/brain/119.4.1123

182. Violet M, Chauderlier A, Delattre L, Tardivel M, Chouala MS, Sultan A et al (2015) Prefibrillar Tau oligomers alter the nucleic acid protective function of Tau in hippocampal neurons in vivo. Neurobiol Dis 82:540-551. https://doi.org/10.1016/j. nbd.2015.09.003

183. Violet M, Delattre L, Tardivel M, Sultan A, Chauderlier A, Caillierez R et al (2014) A major role for Tau in neuronal DNA and RNA protection in vivo under physiological and hyperthermic conditions. Front Cell Neurosci 8:84. https://doi.org/10.3389/ fncel.2014.00084

184. Wang LJ, Huang HY, Huang MP, Liou W, Chang YT, Wu CC et al (2014) The microtubule-associated protein EB1 links AIM2 inflammasomes with autophagy-dependent secretion. J Biol Chem 289:29322-29333. https://doi.org/10.1074/jbc. M114.559153

185. Wang Y, Balaji V, Kaniyappan S, Kruger L, Irsen S, Tepper K et al (2017) The release and trans-synaptic transmission of Tau via exosomes. Mol Neurodegener 12:5. https://doi.org/10.1186/ s13024-016-0143-y

186. Wegmann S, Bennett RE, Amaral AS, Hyman BT (2017) Studying tau protein propagation and pathology in the mouse brain using adeno-associated viruses. Methods Cell Biol 141:307-322. https://doi.org/10.1016/bs.mcb.2017.06.014

187. Wegmann S, Maury EA, Kirk MJ, Saqran L, Roe A, DeVos SL et al (2015) Removing endogenous tau does not prevent tau propagation yet reduces its neurotoxicity. EMBO J 34:3028-3041. https://doi.org/10.15252/embj.201592748

188. Weisova P, Cehlar O, Skrabana R, Zilkova M, Filipcik P, Kovacech B et al (2019) Therapeutic antibody targeting microtubulebinding domain prevents neuronal internalization of extracellular 
tau via masking neuron surface proteoglycans. Acta Neuropathol Commun 7:129. https://doi.org/10.1186/s40478-019-0770-y

189. Williams DR, Holton JL, Strand C, Pittman A, de Silva R, Lees AJ et al (2007) Pathological tau burden and distribution distinguishes progressive supranuclear palsy-parkinsonism from Richardson's syndrome. Brain 130:1566-1576. https://doi. org/10.1093/brain/awm104

190. Winston CN, Goetzl EJ, Akers JC, Carter BS, Rockenstein EM, Galasko D et al (2016) Prediction of conversion from mild cognitive impairment to dementia with neuronally derived blood exosome protein profile. Alzheimers Dement (Amst) 3:63-72. https://doi.org/10.1016/j.dadm.2016.04.001

191. Wu JW, Herman M, Liu L, Simoes S, Acker CM, Figueroa H et al (2013) Small misfolded Tau species are internalized via bulk endocytosis and anterogradely and retrogradely transported in neurons. J Biol Chem 288:1856-1870. https://doi.org/10.1074/ jbc.M112.394528

192. Yamada K, Cirrito JR, Stewart FR, Jiang H, Finn MB, Holmes $\mathrm{BB}$ et al (2011) In vivo microdialysis reveals age-dependent decrease of brain interstitial fluid tau levels in P301S human tau transgenic mice. J Neurosci 31:13110-13117. https://doi. org/10.1523/JNEUROSCI.2569-11.2011

193. Yamada K, Patel TK, Hochgrafe K, Mahan TE, Jiang H, Stewart FR et al (2015) Analysis of in vivo turnover of tau in a mouse model of tauopathy. Mol Neurodegener 10:55. https://doi. org/10.1186/s13024-015-0052-5

194. Yanamandra K, Kfoury N, Jiang H, Mahan TE, Ma S, Maloney SE et al (2013) Anti-tau antibodies that block tau aggregate seeding in vitro markedly decrease pathology and improve cognition in vivo. Neuron 80:402-414. https://doi.org/10.1016/j.neuro n.2013.07.046

195. Yanamandra K, Patel TK, Jiang H, Schindler S, Ulrich JD, Boxer AL et al (2017) Anti-tau antibody administration increases plasma tau in transgenic mice and patients with tauopathy. Sci Transl Med. https://doi.org/10.1126/scitranslmed.aal2029
196. Yang CC, Chiu MJ, Chen TF, Chang HL, Liu BH, Yang SY (2018) Assay of plasma phosphorylated tau protein (Threonine 181 ) and total tau protein in early-stage Alzheimer's disease. J Alzheimers Dis 61:1323-1332. https://doi.org/10.3233/JAD170810

197. Yang SY, Chiu MJ, Chen TF, Lin CH, Jeng JS, Tang SC et al (2017) Analytical performance of reagent for assaying tau protein in human plasma and feasibility study screening neurodegenerative diseases. Sci Rep 7:9304. https://doi.org/10.1038/s4159 8-017-09009

198. Yetman MJ, Lillehaug S, Bjaalie JG, Leergaard TB, Jankowsky JL (2016) Transgene expression in the Nop-tTA driver line is not inherently restricted to the entorhinal cortex. Brain Struct Funct 221:2231-2249. https://doi.org/10.1007/s00429-015-1040-9

199. Zemlan FP, Mulchahey JJ, Gudelsky GA (2003) Quantification and localization of kainic acid-induced neurotoxicity employing a new biomarker of cell death: cleaved microtubule-associated protein-tau (C-tau). Neuroscience 121:399-409. https://doi. org/10.1016/s0306-4522(03)00459-7

200. Zetterberg H, Wilson D, Andreasson U, Minthon L, Blennow K, Randall J et al (2013) Plasma tau levels in Alzheimer's disease. Alzheimers Res Ther 5:9. https://doi.org/10.1186/alzrt163

201. Zhang X, Lin Y, Eschmann NA, Zhou H, Rauch JN, Hernandez I et al. (2017) RNA stores tau reversibly in complex coacervates. PLoS Biol 15:e2002183. https://doi.org/10.1371/journ al.pbio. 2002183

Publisher's Note Springer Nature remains neutral with regard to jurisdictional claims in published maps and institutional affiliations. 